\title{
Hydride, alkyl and carbyne derivatives of the unsaturated heterometallic anion $\left[\mathrm{MoWC}_{2}\left(\mu-\mathrm{PCy}_{2}\right)(\mu-\mathrm{CO})_{2}\right]^{-}$.
}

\author{
M. Angeles Alvarez, M. Esther García, Daniel García-Vivó,* Estefanía Huergo, and \\ Miguel A. Ruiz* \\ Departamento de Química Orgánica e Inorgánica/IUQOEM, Universidad de Oviedo, E-33071 \\ Oviedo, Spain.
}

\begin{abstract}
The heterometallic hydride $\left.\left[\mathrm{MoWCp}_{2}(\mu-\mathrm{H})(\mu-\mathrm{PCy})_{2}\right)(\mathrm{CO})_{4}\right]$ was prepared in $30 \%$ yield through reaction of an equimolar mixture of $\left[\mathrm{Mo}_{2} \mathrm{Cp}_{2}(\mathrm{CO})_{6}\right]$ and $\left[\mathrm{W}_{2} \mathrm{Cp}_{2}(\mathrm{CO})_{6}\right]$ with a two-fold excess of $\mathrm{PHCy}_{2}$ in xylene solution, in a sealed tube at $453 \mathrm{~K}$. The sodium salt of the title anion was then prepared from the latter hydride in a three-step process first involving dehydrogenation with $\mathrm{HBF}_{4} \cdot \mathrm{OEt}_{2}$ in dichloromethane to give the cationic derivative $\left[\mathrm{MoWCp}_{2}\left(\mu-\mathrm{PCy}_{2}\right)(\mathrm{CO})_{4}\right]\left(\mathrm{BF}_{4}\right)$, then reaction of the latter with $\mathrm{NaI}$ in refluxing 1,2-dichloroethane to yield the iodide-bridged dicarbonyl complex $\left[\mathrm{MoWCp}_{2}(\mu-\mathrm{I})\left(\mu-\mathrm{PCy}_{2}\right)(\mathrm{CO})_{2}\right]$ and, finally, reaction of the latter with $\mathrm{Na}(\mathrm{Hg})$ in tetrahydrofuran solution. Reaction of this anion with $\left(\mathrm{NH}_{4}\right) \mathrm{PF}_{6}$ gave the hydride $\left[\mathrm{MoWCp}_{2}(\mathrm{H})\left(\mu-\mathrm{PCy}_{2}\right)(\mathrm{CO})_{2}\right]$, which in solution displays an equilibrium mixture of two isomers, one with terminal carbonyls and the hydride ligand bridging the metal atoms (B), another one with a semibridging carbonyl and the hydride ligand terminally bound to the $\mathrm{W}$ atom $(\mathbf{T})$. The prevalence of isomer $\mathbf{T}$ was higher than the observed ones in the corresponding homometallic analogues, and there was a clear thermodynamic preference of the hydride ligand for the $\mathrm{W}$ site, estimated in some $20 \mathrm{~kJ} / \mathrm{mol}$ according to density functional theory (DFT) calculations. The title anion reacted selectively with benzyl chloride at room temperature, to give the agostic benzyl-bridged derivative [MoWCp $\left.2\left(\mu-\kappa^{1}: \eta^{2}-\mathrm{CH}_{2} \mathrm{Ph}\right)(\mu-\mathrm{PCy})(\mathrm{CO})_{2}\right]$, which displays specific $\kappa^{1}$-coordination to the $\mathrm{W}$ atom $(\mathrm{Mo}-\mathrm{W}=2.580(1) \AA)$, while the analogous reaction with MeI gave a mixture of the related methyl-bridged complex $\left[\mathrm{MoWCp}_{2}\left(\mu-\kappa^{1}: \eta^{2}-\mathrm{CH}_{3}\right)(\mu-\mathrm{PCy})(\mathrm{CO})_{2}\right]$ and its methoxycarbyne-bridged isomer $\left[\mathrm{MoWCp}_{2}(\mu\right.$-COMe $\left.)\left(\mu-\mathrm{PCy}_{2}\right)(\mu-\mathrm{CO})\right]$ in a ratio of ca. 5:1, with the latter corresponding to a chemical behaviour intermediate between those of its homonuclear analogues. Photolysis of the above alkyl complexes with visible-UV light at room temperature resulted in fast decarbonylation followed by dehydrogenation, to give the corresponding carbyne-bridged derivatives $\left[\operatorname{MoWCp}_{2}(\mu\right.$ $\left.\mathrm{CR})\left(\mu-\mathrm{PCy} \mathrm{y}_{2}\right)(\mu-\mathrm{CO})\right](\mathrm{R}=\mathrm{H}, \mathrm{Ph})$ in good yield. This suggests that the cooperative action of $\mathrm{Mo}$ and $\mathrm{W}$ atoms greatly reduces the thermal barrier of the $\mathrm{C}-\mathrm{H}$ bond cleavage steps required for dehydrogenation of the alkyl ligands in these substrates.
\end{abstract}


Keywords: Heterometallic complexes; Metal-metal interactions; Carbonylate complexes;

Hydride complexes; Carbyne complexes; Agostic complexes.

\section{Introduction}

Mononuclear transition-metal carbonylates are classical reagents in organometallic chemistry. Due to their good nucleophilic properties, these anionic metal complexes react under mild conditions with a large variety of electrophilic molecules, whereby new bonds can be made between the metal atom and virtually any other element in the periodic table [1]. Even after many decades of extensive research, however, interesting new findings are just appearing in the field, as novel anions with unusual structures, electron counts, or metal atoms are being unveiled [2]. Compared to this state of facts, the chemistry of binuclear carbonylates has been much less developed, due to the scarce number of species available for reactivity studies. This is particularly so in the case of binuclear anions bearing metal-metal multiple bonds, of which only a few examples are known, and even fewer of them can be properly used in synthetic studies, these being essentially limited to the 32-electron complexes $\left[\mathrm{Mn}_{2}(\mathrm{CO})_{6}\left(\mu-\mathrm{Ph}_{2} \mathrm{PCH}_{2} \mathrm{PPh}_{2}\right)\right]^{2-}[3]$, and $\left[\mathrm{Fe}_{2}\left(\mu-\mathrm{PPh}_{2}\right)(\mathrm{CO})_{6}\right]^{-}[4]$, with $\mathrm{M}=\mathrm{M}$ bonds, and to the 30-electron complexes $\left[\mathrm{M}_{2} \mathrm{Cp}_{2}(\mu-\right.$ $\left.\left.\mathrm{PR}_{2}\right)(\mu-\mathrm{CO})_{2}\right]^{-}\left(\mathrm{M}=\mathrm{Mo}, \mathrm{R}=\mathrm{Cy}[5],{ }^{t} \mathrm{Bu}[6] ; \mathrm{M}=\mathrm{W}, \mathrm{R}=\mathrm{Cy}[7]\right)$, which display $\mathrm{M} \equiv \mathrm{M}$ bonds. Extensive studies carried out in our lab on the latter dicarbonyl anions have shown that the combined presence of negative charge and an intermetallic multiple bond confers a wide synthetic potential to these complexes, this enabling the synthesis of a great variety of derivatives with many different functionalities including, inter alia, bridging hydride, alkyl, alkenyl and carbyne ligands. Such synthetic versatility in turn derives from the activity of two distinct nucleophilic sites in these anions, located at the dimetal site and oxygen atoms of the bridging carbonyls, respectively [8].

The above studies have also revealed a significant influence of the metal (Mo vs. W) on the reactivity of these unsaturated anions, which is well exemplified by the protonation and methylation reactions of the $\mathrm{PCy}_{2}$-bridged anions (Scheme 1). Thus, while protonation of the $\mathrm{Mo}_{2}$ anion with $\left(\mathrm{NH}_{4}\right) \mathrm{PF}_{6}$ gives a hydride-bridged product, the $\mathrm{W}_{2}$ anion renders an equilibrium mixture of two isomers, which bear either bridging or terminal hydride ligands, respectively (B and $\mathbf{T}$ in Scheme 1) [7b, 9-11]. On the other hand, while reaction of the $\mathrm{Mo}_{2}$ anion with MeI results in electrophile attachment at the dimetal site to yield an agostic methyl-bridged derivative, the analogous reaction of the $\mathrm{W}_{2}$ anion gives a mixture of the related methyl complex (minor product) and the methoxycarbyne-bridged isomer following from electrophile attachment at the oxygen atom of a bridging carbonyl (major product), this proving the higher nucleophilicity of the $\mathrm{O}$-site at the ditungsten anion [7a]. 


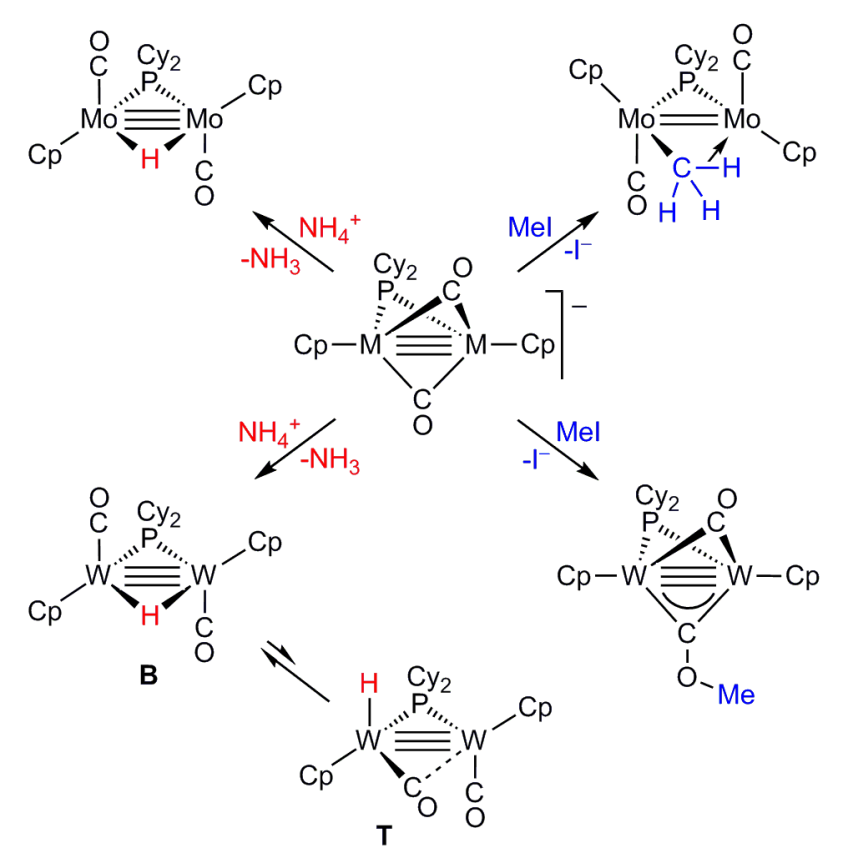

\section{Scheme 1}

Having realized the significant influence of the metal on the chemistry of these anions, we then undertook a search for related unsaturated anions containing $\mathrm{Mo} \equiv \mathrm{W}$ bonds, so to examine the effects that the presence of such intermetallic multiple bond would have on the reactivity of these anionic species, such as site selectivity and cooperative effects, and also on the structure of their neutral derivatives. We note that, although there is currently a substantial research activity around coordination compounds bearing heterometallic multiple bonds [12], there are only few studies concerning related organometallic compounds $[13,14]$. Of particular relevance in the context of 30-electron complexes is the finding by Suzuki et al. that the unsaturated hydride $\left[\mathrm{Cp}^{*} \mathrm{Ru}(\mu-\mathrm{H})_{4} \mathrm{OsCp} *\right]$ undergoes addition reactions at a rate much higher than the rates measured for the corresponding homometallic complexes having $\mathrm{Ru}-\mathrm{Ru}$ or Os-Os bonds, thus proving the operation of a true cooperative kinetic effect in this heterometallic system [14d]. In this paper we report an efficient preparative route to the 30 -electron heterometallic anion $\left[\operatorname{MoWCp}_{2}\left(\mu-\mathrm{PCy}_{2}\right)(\mu-\mathrm{CO})_{2}\right]^{-}$, which is the first reported carbonyl anion with an heterometallic triple bond, and a study on the formation and structure of some of their neutral derivatives bearing hydride, alkyl or carbyne ligands. As will be shown below, these studies prove the operation of definite structural effects (coordination preferences), and also suggest that the cooperative action of Mo and $\mathrm{W}$ greatly reduces the thermal barrier of the $\mathrm{C}-\mathrm{H}$ bond cleavage steps required for dehydrogenation of alkyl ligands at these heterometallic centres. 


\section{Results and Discussion}

\subsection{Synthesis of the heterometallic hydride precursor 1.}

The formation of homometallic anions $\left[\mathrm{M}_{2} \mathrm{Cp}_{2}(\mu-\mathrm{PCy})(\mu-\mathrm{CO})_{2}\right]^{-}(\mathrm{M}=\mathrm{Mo}, \mathrm{W})$ ultimately relies on the reduction of the corresponding halide-bridged complexes $\left[\mathrm{M}_{2} \mathrm{Cp}_{2}(\mu-\mathrm{X})\left(\mu-\mathrm{PCy}_{2}\right)(\mathrm{CO})_{2}\right]$, which in turn can be prepared either through direct reaction of $\left[\mathrm{M}_{2} \mathrm{Cp}_{2}(\mathrm{CO})_{6}\right]$ with chlorophosphine $\mathrm{PCy}_{2} \mathrm{Cl}$, when $\mathrm{M}=\mathrm{Mo}$ [5], or via a two-step reaction starting from the electron-precise hydride $\left[\mathrm{M}_{2} \mathrm{Cp}_{2}(\mu-\mathrm{H})(\mu\right.$ $\left.\left.\mathrm{PCy}_{2}\right)(\mathrm{CO})_{4}\right]$, when $\mathrm{M}=\mathrm{W}$ [7]. The latter proved to be the only successful route to our targeted halide-bridged intermediate $\left[\mathrm{MoWCp}_{2}(\mu-\mathrm{X})\left(\mu-\mathrm{PCy}_{2}\right)(\mathrm{CO})_{2}\right]$, but this in turn required implementing an efficient preparation for the corresponding heterometallic precursor, the new hydride complex $\left[\operatorname{MoWCp}_{2}(\mu-\mathrm{H})\left(\mu-\mathrm{PCy}_{2}\right)(\mathrm{CO})_{4}\right](\mathbf{1})$. Attempts to prepare compound $\mathbf{1}$ through the routes used previously to synthesize related homometallic complexes $\left[\mathrm{M}_{2} \mathrm{Cp}_{2}(\mu-\mathrm{H})\left(\mu\right.\right.$-PRR')(CO) 4 (reactions of $\left[\mathrm{M}_{2} \mathrm{Cp}_{2}(\mathrm{CO})_{6}\right]$ or $\left[\mathrm{M}_{2} \mathrm{Cp}_{2}(\mathrm{CO})_{4}\right]$ with HPRR', or reaction of $\left[\mathrm{M}_{2} \mathrm{Cp}_{2}(\mathrm{CO})_{4}\right]$ with LiPRR') $[15,16]$ proved to be inefficient in this case. Eventually, compound $\mathbf{1}$ could be efficiently prepared through a slight modification of the method reported by Haupt et al. to obtain related MoRe hydride complexes [17]. Thus, the reaction of an equimolar mixture of $\left[\mathrm{Mo}_{2} \mathrm{Cp}_{2}(\mathrm{CO})_{6}\right]$ and $\left[\mathrm{W}_{2} \mathrm{Cp}_{2}(\mathrm{CO})_{6}\right]$ with a two-fold excess of $\mathrm{PHCy}_{2}$ in xylene solution, in a sealed tube at $453 \mathrm{~K}$ for $6 \mathrm{~h}$, rendered an almost statistical mixture of the hydridebridged complexes $\left[\mathrm{MM}^{\prime} \mathrm{Cp}_{2}(\mu-\mathrm{H})\left(\mu-\mathrm{PCy}_{2}\right)(\mathrm{CO})_{4}\right]$ (Scheme 2), from which the heterometallic complex 1 could be eventually isolated in ca. $30 \%$ yield after chromatographic workup.

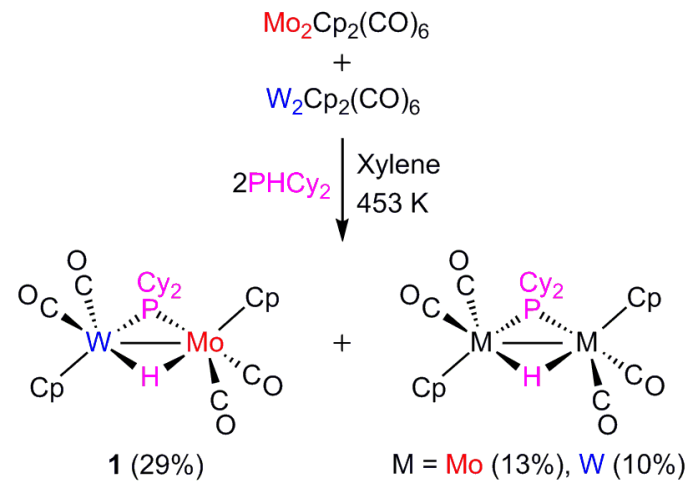

Scheme 2

Spectroscopic data in solution for compound 1 (Table 1 and Experimental section) are comparable to those of the corresponding $\mathrm{Mo}_{2}$ and $\mathrm{W}_{2}$ analogues and related complexes $[15,16]$, and need not to be discussed in detail. All these molecules display a transoid arrangement of their $\mathrm{MCp}(\mathrm{CO})_{2}$ fragments, which has been substantiated 
through X-ray studies in several cases [16, 18]. As expected, compound $\mathbf{1}$ displays ${ }^{31} \mathrm{P}$ $(\delta \mathrm{P} 178.9 \mathrm{ppm})$ and hydride $\left(\delta_{\mathrm{H}}-14.56 \mathrm{ppm}, J_{\mathrm{HP}}=30 \mathrm{~Hz}\right)$ resonances in positions intermediate with respect to its homometallic analogues, with one-bond P-W (197 Hz) and $\mathrm{H}-\mathrm{W}(40 \mathrm{~Hz})$ couplings comparable to those measured in the corresponding ditungsten complex (182 and $40 \mathrm{~Hz}$, respectively). As for the carbonyl ligands of $\mathbf{1}$, the presence of Mo and $\mathrm{W}$ atoms in the same molecule removes all symmetry elements, so all of them become inequivalent, with the ones positioned cis to the $\mathrm{P}$ atom rendering ${ }^{13} \mathrm{C}$ NMR resonances displaying measurable two-bond P-C couplings of ca. $20-30 \mathrm{~Hz}$ as expected $[19,20]$.

Table 1. Selected IR and NMR data for new compounds

\begin{tabular}{|c|c|c|c|}
\hline Compound & $v(\mathrm{CO})^{a}$ & $\delta(\mathrm{P})\left[J_{\mathrm{PW}}\right]^{b}$ & $\delta(\mu-\mathrm{C})\left[J_{\mathrm{CP}}\right]^{b}$ \\
\hline$\left[\mathrm{MoWCp}_{2}(\mu-\mathrm{H})\left(\mu-\mathrm{PCy}_{2}\right)(\mathrm{CO})_{4}\right](\mathbf{1})$ & $1922(v s), 1847(\mathrm{~s})$ & $178.9[197]^{c}$ & \\
\hline$\left[\mathrm{MoWCp}_{2}\left(\mu-\mathrm{PCy}_{2}\right)(\mathrm{CO})_{4}\right]\left(\mathrm{BF}_{4}\right)(\mathbf{2})$ & $\begin{array}{l}2003(\mathrm{~m}), 1961(\mathrm{vs}), 1934(\mathrm{~s}), \\
1907(\mathrm{~m}, \mathrm{sh})\end{array}$ & $170.1[255]$ & \\
\hline$\left[\mathrm{MoWCp}_{2}(\mu-\mathrm{I})\left(\mu-\mathrm{PCy}_{2}\right)(\mathrm{CO})_{2}\right](\mathbf{3})$ & 1866 (m, sh), 1829 (vs) & $125.8[307]^{c}$ & \\
\hline $\mathrm{Na}\left[\mathrm{MoWCp}_{2}\left(\mu-\mathrm{PCy}_{2}\right)(\mu-\mathrm{CO})_{2}\right](4-\mathrm{Na})$ & $1565(\mathrm{vs})^{d}$ & & \\
\hline$\left[\mathrm{MoWCp}_{2}(\mu-\mathrm{H})\left(\mu-\mathrm{PCy}_{2}\right)(\mathrm{CO})_{2}\right](\mathbf{5 B})$ & $1869(\mathrm{w}, \mathrm{sh}), 1821$ (vs) & $197.3[330]^{e}$ & \\
\hline$\left[\mathrm{MoWCp}_{2}(\mathrm{H})\left(\mu-\mathrm{PCy}_{2}\right)(\mathrm{CO})_{2}\right](\mathbf{5 T})$ & $1762(\mathrm{~s})^{f}$ & $232.8[248]^{e}$ & $276.2^{g}$ \\
\hline$\left[\mathrm{MoWCp}_{2}\left(\mu-\kappa^{1}: \eta^{2}-\mathrm{CH}_{3}\right)\left(\mu-\mathrm{PCy}_{2}\right)(\mathrm{CO})_{2}\right](\mathbf{6})$ & $1854(\mathrm{~m}, \mathrm{sh}), 1812(\mathrm{vs})$ & $116.5[310]$ & $-44.6^{h}$ \\
\hline$\left[\mathrm{MoWCp}_{2}(\mu-\mathrm{COMe})\left(\mu-\mathrm{PCy}_{2}\right)(\mu-\mathrm{CO})\right](7)$ & $1653(\mathrm{vs})$ & $194.5[345]$ & $348.3[11]^{c}$ \\
\hline$\left[\mathrm{MoWCp}_{2}\left(\mu-\kappa^{1}: \eta^{2}-\mathrm{CH}_{2} \mathrm{Ph}\right)\left(\mu-\mathrm{PCy}_{2}\right)(\mathrm{CO})_{2}\right](\mathbf{8})$ & $1865(\mathrm{~m}, \mathrm{sh}), 1823(\mathrm{vs})$ & $111.2[305]$ & -3.9 \\
\hline$\left[\mathrm{MoWCp}_{2}(\mu-\mathrm{CH})\left(\mu-\mathrm{PCy}_{2}\right)(\mu-\mathrm{CO})\right](\mathbf{9})$ & 1661 (vs) & $195.0[345]$ & $369.4[11]^{c}$ \\
\hline$\left[\mathrm{MoWCp}_{2}(\mu-\mathrm{CPh})\left(\mu-\mathrm{PCy}_{2}\right)(\mu-\mathrm{CO})\right](\mathbf{1 0})$ & $1662(\mathrm{vs})$ & $199.7[341]$ & $375.0[11]^{c}$ \\
\hline$\left[\mathrm{MoWCp}_{2}\left(\mu-\mathrm{PCy}_{2}\right)_{2}(\mu-\mathrm{CO})\right](\mathbf{1 1})$ & $1638(\mathrm{vs})$ & $203.6[364]^{c}$ & \\
\hline
\end{tabular}

${ }^{a}$ Recorded in dichloromethane solution, data in $\mathrm{cm}^{-1}$.

${ }^{b}$ Recorded at room temperature in $\mathrm{CD}_{2} \mathrm{Cl}_{2}$ solution at $162.01\left({ }^{31} \mathrm{P}\right)$ and $100.63 \mathrm{MHz}\left({ }^{13} \mathrm{C}\right)$, unless otherwise stated; $\delta$ in ppm relative to external $85 \%$ aqueous $\mathrm{H}_{3} \mathrm{PO}_{4}$ and internal tetramethylsilane, respectively, with ${ }^{31} \mathrm{P}_{-}{ }^{183} \mathrm{~W}$ and ${ }^{13} \mathrm{C}_{-}{ }^{31} \mathrm{P}$ coupling constants $\left(\left[J_{\mathrm{PW}}\right]\right.$ and $\left.\left[J_{\mathrm{CP}}\right]\right)$ in $\mathrm{Hz}$.

${ }^{c}$ Recorded in $\mathrm{C}_{6} \mathrm{D}_{6}$.

${ }^{d}$ Recorded in tetrahydrofuran solution.

${ }^{e}$ Recorded at $162.01 \mathrm{MHz}$ and $183 \mathrm{~K}$.

${ }^{f}$ Another $\mathrm{C}-\mathrm{O}$ stretch is obscured by the $1821 \mathrm{~cm}^{-1}$ band of isomer $\mathbf{5 B}$ (see text).

${ }^{g}$ Recorded at $183 \mathrm{~K}$.

${ }^{h}$ Recorded at $233 \mathrm{~K}$.

\subsection{Synthesis and structural characterization of the title anion and its heterometallic} precursors.

As noted above, the title anion could be efficiently prepared using the synthetic route previously developed for the related ditungsten analogue [7], a three-step process starting from the corresponding 34-electron hydride $\left[\mathrm{M}_{2} \mathrm{Cp}_{2}(\mu-\mathrm{H})(\mu-\mathrm{PCy})(\mathrm{CO})_{4}\right]$ (Scheme 3). In the first step, the heterometallic hydride $\mathbf{1}$ is dehydrogenated through reaction with $\mathrm{HBF}_{4} \cdot \mathrm{OEt}_{2}$ in dichloromethane solution, to yield the 32-electron cationic 
derivative $\left[\mathrm{MoWCp}_{2}\left(\mu-\mathrm{PCy}_{2}\right)(\mathrm{CO})_{4}\right]\left(\mathrm{BF}_{4}\right)$ (2). Spectroscopic data for 2 (Table 1 and Experimental section) are comparable to those of its ditungsten analogue [7] and related $\mathrm{PPh}_{2}$-bridged complexes [21]. In particular, we note the significant increase in the $\mathrm{C}-\mathrm{O}$ stretches (relative to $\mathbf{1}$ ) as a result of the presence of a positive charge in the complex, while the increased one-bond P-W coupling (from 197 to $255 \mathrm{~Hz}$ ) reflects the reduction in the number of ligands surrounding the $\mathrm{W}$ atom after dehydrogenation [20].

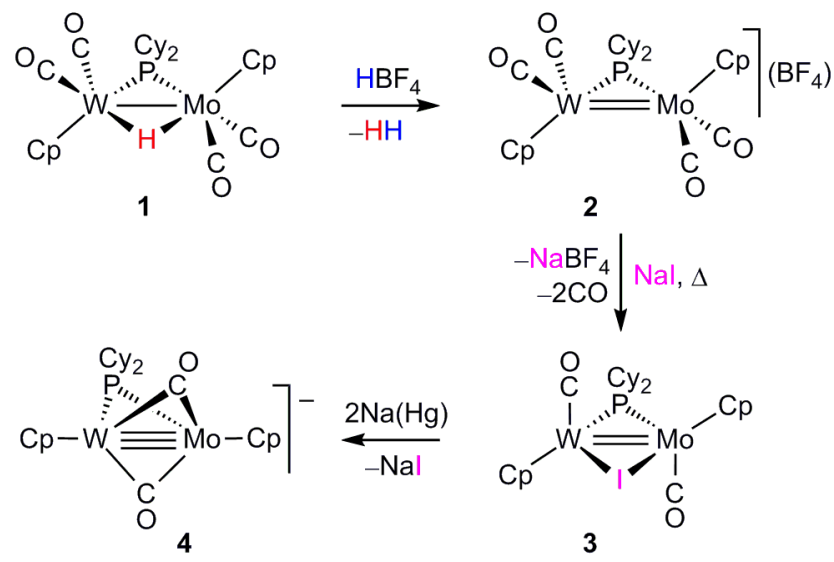

Scheme 3

In the second step, the cationic complex $\mathbf{2}$ is reacted with an excess $\mathrm{NaI}$ in refluxing 1,2-dichloroethane solution, whereby iodide addition and decarbonylation takes place, to yield the iodide-bridged dicarbonyl complex $\left[\mathrm{MoWCp}_{2}(\mu-\mathrm{I})(\mu-\mathrm{PCy} 2)(\mathrm{CO})_{2}\right]$ (3) almost quantitatively. As found for its ditungsten analogue, this 32-electron complex is quite air-sensitive and was used without further purification. Its IR spectrum displays two $\mathrm{C}-\mathrm{O}$ stretching bands with relative intensities (weak and strong, in order of decreasing frequencies) characteristic of transoid $\mathrm{M}_{2}(\mathrm{CO})_{2}$ oscillators [22]. This structural arrangement has been persistently found in all halide-bridged complexes of type $\left[\mathrm{M}_{2} \mathrm{Cp}_{2}(\mu-\mathrm{X})\left(\mu-\mathrm{PR}_{2}\right)(\mathrm{CO})_{2}\right]$ prepared by us previously, and it has been substantiated crystallographically in the case of $\left[\mathrm{Mo}_{2} \mathrm{Cp}_{2}(\mu-\mathrm{Cl})\left(\mu-\mathrm{P}^{t} \mathrm{Bu}_{2}\right)(\mathrm{CO})_{2}\right]$ [6]. The ${ }^{31} \mathrm{P}$ NMR resonance of $\mathbf{3}$ is substantially shielded with respect to $\mathbf{1}$ (125.8 vs. 178.9 ppm), as usually found in this family of neutral complexes, and the one-bond $\mathrm{P}-\mathrm{W}$ coupling is substantially higher (307 vs. $197 \mathrm{~Hz}$ ), thus reflecting the significant reduction in the coordination number around the $\mathrm{W}$ atom after decarbonylation.

In the last step, the iodide-bridged complex 3 is reduced with $\mathrm{Na}(\mathrm{Hg})$ in tetrahydrofuran solution, whereby the sodium salt of the targeted unsaturated anion $\mathrm{Na}\left[\mathrm{MoWCp}_{2}\left(\mu-\mathrm{PCy}_{2}\right)(\mu \text {-CO) })_{2}\right](4-\mathrm{Na})$ is formed in a quantitative way, along with $\mathrm{NaI}$. This product is very air-sensitive and displays low solubility in tetrahydrofuran, thus precluding its analysis by NMR spectroscopy. Its IR spectrum displays a single and strong $\mathrm{C}-\mathrm{O}$ stretch at very low frequency $\left(1565 \mathrm{~cm}^{-1}\right)$, in a position intermediate with respect to those measured for the analogous $\mathrm{Mo}_{2}$ and $\mathrm{W}_{2}$ complexes (1580 and 1546 
$\mathrm{cm}^{-1}$, respectively), which corresponds to the asymmetric stretch for the $\mathrm{M}_{2}(\mu-\mathrm{CO})_{2}$ oscillator of these anions. The expected and weaker band corresponding to the symmetric stretch probably is too close to the latter band, to be observed separately.

We have shown previously that strong ion-pairing effects are present in the solutions of these unsaturated anions, which are in turn strongly dependent on their counter-ion [5a]; this is also the case for the heterometallic anion 4. For instance, the lithium salt $\mathrm{Li}\left[\mathrm{MoWCp}_{2}\left(\mu-\mathrm{PCy}_{2}\right)(\mu-\mathrm{CO})_{2}\right]$ (4-Li) could be analogously prepared by reacting 3 with $\mathrm{Li}(\mathrm{Hg})$ in tetrahydrofuran solution. Interestingly, as found for its $\mathrm{Mo}_{2}$ analogue, the IR spectrum of this salt now displays three C-O stretches at 1642 (w), 1573 (m, sh) and $1552(\mathrm{~s}) \mathrm{cm}^{-1}$, with the latter two bands likely corresponding respectively to the symmetric and asymmetric stretches of the isolated anion (with unspecific cation-anion interactions), while the band at $1642 \mathrm{~cm}^{-1}$ can be attributed to the $\mathrm{C}-\mathrm{O}$ stretch of a tight ion pair involving the attachment of the $\mathrm{Li}^{+}$cation to one of the bridging carbonyls [5a].

\subsection{Formation and structural characterization of the hydride complex 5.}

The sodium salt of anion 4 reacts readily with the weak acid $\left(\mathrm{NH}_{4}\right) \mathrm{PF}_{6}$ in tetrahydrofuran solution to give the corresponding hydride $\left[\mathrm{MoWCp}_{2}(\mathrm{H})(\mu-\right.$ $\left.\left.\mathrm{PCy}_{2}\right)(\mathrm{CO})_{2}\right](5)$, which can be isolated in good yield as a pure substance upon chromatographic workup. Protonation of $\mathbf{4}$ with strong acids such as $\mathrm{HBF}_{4} \cdot \mathrm{OEt}_{2}$ led only to complex mixtures of unstable products. We note, however, that the protonation process leading to $\mathbf{5}$ is fully reversible, since 4-Na can be selectively regenerated upon stirring a tetrahydrofuran solution of 5 with $\mathrm{Na}(\mathrm{Hg})$ for a few minutes.

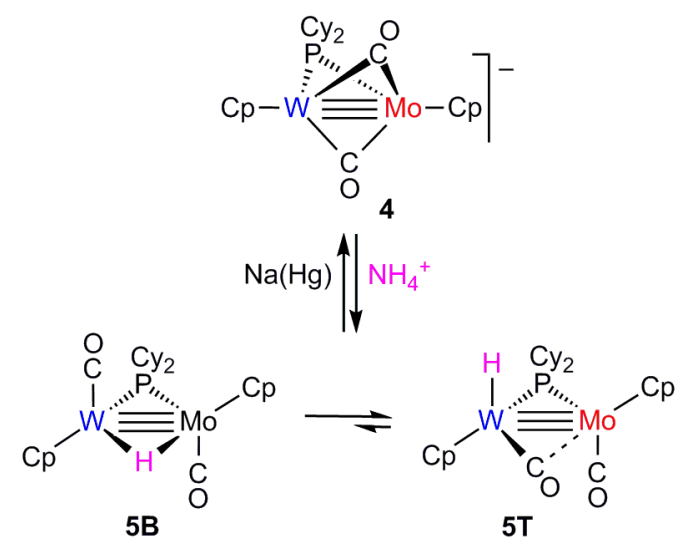

Scheme 4

Complex 5 exists in solution as an equilibrium mixture of two isomers, one with terminal carbonyls and the hydride ligand bridging the metal atoms $(\mathbf{5 B})$, another one with a semibridging carbonyl and the hydride ligand terminally bound to the $\mathrm{W}$ atom (5T) (Scheme 4), as previously found for its ditungsten analogue (Scheme 1). These structural types have been characterized crystallographically for the dimolybdenum 
complexes $\left[\mathrm{Mo}_{2} \mathrm{Cp}_{2}(\mu-\mathrm{H})(\mu-\mathrm{PCy})(\mathrm{CO})_{2}\right]$ (isomer B) [23], and $\left[\mathrm{Mo}_{2} \mathrm{Cp}_{2}(\mathrm{H})(\mu-\right.$ $\left.\mathrm{P}^{t} \mathrm{Bu}_{2}\right)(\mathrm{CO})_{2}$ ] (isomer $\mathbf{T}$ ) [6]; the latter complexes, however, displayed in solution a single isomer in each case. In the case of $\mathbf{5}$, the isomer ratio $\mathbf{T} / \mathbf{B}$ expectedly was solvent- and temperature-dependent but, interestingly, has a value outside the range spanned by its homometallic analogues (T/B ca. 0 and 0.33 in $\mathrm{CD}_{2} \mathrm{Cl}_{2}$ solution at $193 \mathrm{~K}$ respectively for the $\mathrm{Mo}_{2}$ and $\mathrm{W}_{2}$ analogues), since under analogous conditions the terminal isomer $\mathbf{5 T}$ is the major species in solution $(\mathbf{5 T} / \mathbf{5 B}=2.5$ at $183 \mathrm{~K})$. This can be then considered as a genuine heterometallic effect of structural nature. Isomer 5T was also found to be favoured over isomer $\mathbf{5 B}$ on lowering the temperature, but disfavoured when using a less polar solvent as toluene- $d_{8}(\mathbf{5 T} / \mathbf{5 B}=0.6$ at $183 \mathrm{~K}$ ) (see the Experimental section). In any case, all of this means that the energetic difference between these two isomers in $\mathbf{5}$ is very small, in agreement with density functional theory (DFT) calculations [24] discussed below.

Spectroscopic data for isomers 5B and 5T are comparable to those of their homometallic analogues where applicable, and need not to be discussed in detail. The presence of the terminal isomer $\mathbf{5 T}$ at room temperature is denoted by the appearance of a $\mathrm{C}-\mathrm{O}$ stretch at $1762 \mathrm{~cm}^{-1}$ in the IR spectrum, indicative of the presence of a semibridging carbonyl ligand, in addition to the more energetic bands at 1869 (w, sh) and 1821 (vs) $\mathrm{cm}^{-1}$ expected for the stretches of antiparallel terminal carbonyls in the hydride-bridged isomer 5B. Separate NMR resonances could be observed for both isomers at low temperature (see the Experimental section), with the terminal isomer $\mathbf{5 T}$ reproducing the spectroscopic features of its ditungsten analogue: (a) a ${ }^{31} \mathrm{P}$ NMR resonance more deshielded than isomer 5B ( $\delta$ P 232.8 vs. $197.3 \mathrm{ppm}$ ); (b) a lower onebond $\mathrm{P}-\mathrm{W}$ coupling $(248$ vs. $330 \mathrm{~Hz}$ ), as expected from the higher coordination number at the $\mathrm{W}$ atom; (c) a less shielded hydride resonance $(\delta \mathrm{H}-1.46$ vs. $-6.41 \mathrm{ppm})$, indicative of its terminal coordination, with a high $\mathrm{H}-\mathrm{W}$ coupling of $70 \mathrm{~Hz}$ which denotes its attachment specifically at the W site (cf. $\delta-0.71 \mathrm{ppm}, J_{\mathrm{HW}}=99 \mathrm{~Hz}$ for its $\mathrm{W}_{2}$ analogue); and (d) a strong deshielding of the W-bound carbonyl ( $\delta_{\mathrm{C}} 276.2 \mathrm{ppm}$ ) indicative of its semibridging character (cf. $272.7 \mathrm{ppm}$ in its $\mathrm{W}_{2}$ analogue). All these data provide conclusive evidence for a clear preference of the hydride ligand in $\mathbf{5}$ for terminal coordination specifically at the $\mathrm{W}$ site, a matter further analysed below.

\subsubsection{DFT calculations on hydride 5.}

To gain more insight concerning the structures and relative stability of different isomers of compound $\mathbf{5}$ in solution we have performed DFT calculations on the observed isomers 5B and 5T, and also on a third isomer similar to the latter one, but with the hydride ligand terminally bound to the Mo atom, and the Mo-bound carbonyl involved in semibridging interaction with the $\mathrm{W}$ atom (5T-Mo) (Figure 1 and Table 2, 
see the Experimental section and Supplementary data). The latter isomer displays a structure essentially equivalent to that of $\mathbf{5 T}$, but was computed to be some $20 \mathrm{~kJ} / \mathrm{mol}$ less stable than $\mathbf{5 T}$ in the gas phase, which is consistent with the experimental fact that no significant amounts of such isomer are detected spectroscopically in solution, and with the general finding that $\mathrm{W}-\mathrm{H}$ bonds are generally stronger than $\mathrm{Mo}-\mathrm{H}$ bonds in comparable organometallic species [25]. Therefore we can conclude that the observed preference of the hydride ligand for terminal coordination at the W (instead of Mo) site is of thermodynamic origin.

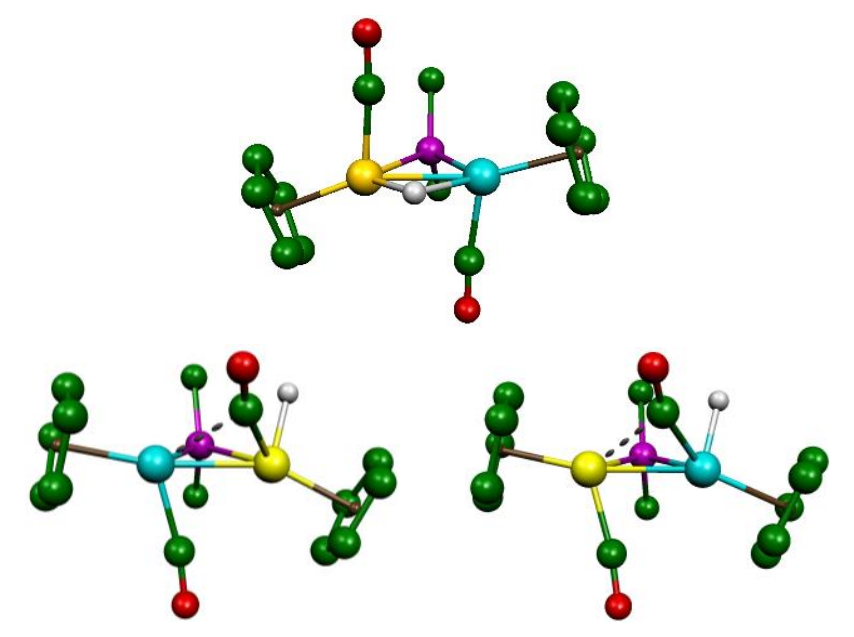

Figure 1. B3LYP-optimized structures for isomers 5B (upper, blue colour for Mo), 5T (lower, left) and 5T-Mo (lower, right), with $\mathrm{H}$ atoms (except hydride ligands) and $\mathrm{Cy}$ groups (except $\mathrm{C}^{1}$ atoms) omitted for clarity. Relative Gibbs free energies at $295 \mathrm{~K}$ were $0,+11$ and $+31 \mathrm{~kJ} / \mathrm{mol}$ respectively.

Table 2. B3LYP-computed bond lengths $(\AA)$ and angles $\left({ }^{\circ}\right)$ for different isomers of compound 5

\begin{tabular}{|c|c|c|c|}
\hline parameter & 5B & $5 T$ & 5T-Mo \\
\hline W-Mo & 2.544 & 2.536 & 2.531 \\
\hline $\mathrm{W}-\mathrm{P}$ & 2.427 & 2.452 & 2.395 \\
\hline Mo-P & 2.449 & 2.413 & 2.476 \\
\hline $\mathrm{W}-\mathrm{CO}$ & 1.950 & 1.982 & 1.945 \\
\hline $\mathrm{W} \cdots \mathrm{CO}$ & & 2.775 & 2.395 \\
\hline $\mathrm{Mo}-\mathrm{CO}$ & 1.953 & 1.951 & 1.990 \\
\hline $\mathrm{Mo} \cdots \mathrm{CO}$ & & 2.442 & 2.761 \\
\hline $\mathrm{W}-\mathrm{H}$ & 1.851 & 1.707 & \\
\hline Mo-H & 1.895 & & 1.692 \\
\hline $\mathrm{W}-\mathrm{C}-\mathrm{O}$ & 175.5 & 166.1 & 172.4 \\
\hline Mo-C-O & 173.9 & 171.1 & 162.6 \\
\hline $\mathrm{W}-\mathrm{Mo}-\mathrm{CO}$ & 81.3 & 74.5 & 62.6 \\
\hline $\mathrm{Mo}-\mathrm{W}-\mathrm{CO}$ & 84.3 & 64.1 & 74.9 \\
\hline
\end{tabular}

Concerning the geometries computed for the observed isomers $\mathbf{5 B}$ and $\mathbf{5 T}$, we notice that the structural parameters for these molecules at the B3LYP level are in good agreement with those determined crystallographically for the dimolybdenum hydrides $\left[\mathrm{Mo}_{2} \mathrm{Cp}_{2}(\mu-\mathrm{H})(\mu-\mathrm{PCy})(\mathrm{CO})_{2}\right]$ and $\left[\mathrm{Mo}_{2} \mathrm{Cp}_{2}(\mathrm{H})\left(\mu-\mathrm{P}^{t} \mathrm{Bu}_{2}\right)(\mathrm{CO})_{2}\right]$ respectively $[22,6]$, although the computed distances involving the metal atoms are slightly higher than the experimental values in the $\mathrm{Mo}_{2}$ complexes, as commonly found at this level of calculation [24]. These structures in turn are comparable to those computed at the same 
level for isomers of type $\mathbf{B}$ and $\mathbf{T}$ for the above $\mathrm{P}^{t} \mathrm{Bu}_{2}$-bridged complex, or for the ditungsten analogue of $\mathbf{5}$, which we have analysed previously in detail [7b, 9]. Then, only a few comments are to be added: (a) The intermetallic separation in isomers $\mathbf{5 B}$ and 5 T (ca. $2.54 \AA$ ) is very short and similar to each other, in line with our general view that the triply bonding intermetallic interaction in this sort of complex is not significantly modified by the coordination mode (bridging or terminal) of the hydride ligand [11b]; (b) The carbonyl bound to the metal atom bearing the terminal hydride (W) is involved in a significant semibridging interaction with the other metal atom (Mo), as denoted by the Mo $\cdots$ CO length of $2.442 \AA$, in agreement with the ${ }^{13} \mathrm{C}$ NMR data discussed above, while the $\mathrm{W}-\mathrm{C}-\mathrm{O}$ angle remains high $\left(166.1^{\circ}\right)$, this enabling its classification as linear semibridging of type II [26], which is a common structural feature of compounds displaying intermetallic triple bonds; the Mo-bound carbonyl displays a much longer separation to the $\mathrm{W}$ atom (W... CO 2.775 $\AA$ ) and then must be considered as essentially terminal.

Our calculations at the B3LYP level predict that the hydride-bridged isomer 5B is more stable (by $11 \mathrm{~kJ} / \mathrm{mol}$ ) than the terminal isomer $\mathbf{5 T}$ in the gas phase, which is consistent with the experimental fact that $\mathbf{5 B}$ is the major species in toluene- $d_{8}$ solution at $183 \mathrm{~K}$. Dispersion forces seem to be of no critical role on the relative stability of these isomers, as inclusion of the Grimme correction in our calculations (see the Experimental section) only reduced from 11 to $9.5 \mathrm{~kJ} / \mathrm{mol}$ the energy difference between isomers. However, as noted above, isomer $\mathbf{5 T}$ is the major species in dichloromethane solution at all temperatures. Inclusion of solvation effects (see the Experimental section) only marginally reduced the energetic difference between these isomers (to ca. $8 \mathrm{~kJ} / \mathrm{mol}$ ), but still did not reproduce the experimental prevalence of $\mathbf{5 T}$ in such solvent. This might suggest that interactions between the terminal isomer 5T and the dichloromethane molecules might be more specific than conventional dipoledipole interactions, perhaps being of hydrogen-bond nature. Interestingly, hydrogenbond interactions between the hydride complex $\left[\mathrm{WCp}(\mathrm{CO})_{3} \mathrm{H}\right]$ and dichloromethane molecules have been computed to be of significant strength (ca $9 \mathrm{~kJ} / \mathrm{mol}$ ) [27], enough to influence in our case the thermodynamic balance between isomers $\mathbf{5 B}$ and $\mathbf{5 T}$ in solution.

\subsection{Reactions of anion 4 with alkyl halides.}

The sodium salt of anion 4 reacts slowly with excess MeI at room temperature in tetrahydrofuran solution, to give a mixture of the methyl-bridged complex $\left[\operatorname{MoWCp}_{2}(\mu-\right.$ $\left.\left.\kappa^{1}: \eta^{2}-\mathrm{CH}_{3}\right)(\mu-\mathrm{PCy})(\mathrm{CO})_{2}\right](6)$ and its methoxycarbyne-bridged isomer $\left[\mathrm{MoWCp}_{2}(\mu-\right.$ $\left.\mathrm{COMe})\left(\mu-\mathrm{PCy}_{2}\right)(\mu-\mathrm{CO})\right](7)$, in a ratio of ca. 5:1 (Scheme 5). This corresponds to a chemical behaviour intermediate between those of its homometallic analogues, which in 
the same reaction instead yielded only the methyl derivative $\left(\mathrm{Mo}_{2}\right)$ or mostly the methoxycarbyne isomer $\left(\mathrm{W}_{2}\right)$, as noted above (Scheme 1). Expectedly, the carbyne complex 7 could be selectively prepared by using a stronger methylating reagent [5a], in this case methyl sulfate (see the Experimental section). In contrast, Na-4 reacts selectively with benzyl chloride under the same conditions, to give the benzyl-bridged derivative $\left[\mathrm{MoWCp}_{2}\left(\mu-\kappa^{1}: \eta^{2}-\mathrm{CH}_{2} \mathrm{Ph}\right)(\mu-\mathrm{PCy})(\mathrm{CO})_{2}\right](\mathbf{8})$ as the sole product, as found for the $\mathrm{Mo}_{2}$ and $\mathrm{W}_{2}$ related anions.

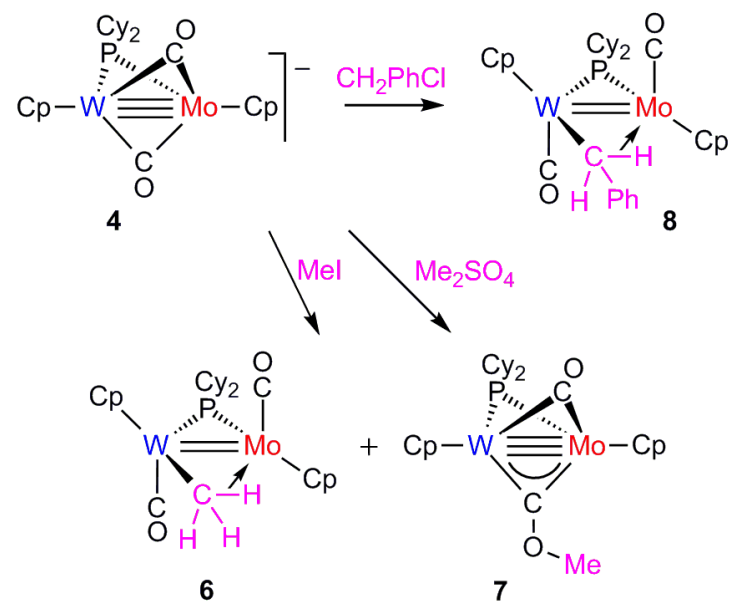

Scheme 5

\subsubsection{Solid-state and solution structure of the agostic benzyl-bridged complex 8 .}

The molecule of $\mathbf{8}$ in the crystal (Figure 2 and Table 3) is built from two transoid $\mathrm{MCp}(\mathrm{CO})$ fragments bridged by a PCy2 group and an agostic methyl ligand which is $\kappa^{1}-$ bound to the tungsten atom $(\mathrm{W}-\mathrm{C}=2.26(2) \AA)$ and $\eta^{2}$-bound to the Mo atom via a $\mathrm{C}-\mathrm{H}$ bond (Mo-C $=2.40(2), \mathrm{Mo}-\mathrm{H}=2.00(2) \AA$ ), whereby it formally contributes with three electrons to the dimetal site, which in turn leads to the proposal for $\mathbf{8}$ of an intermetallic double bond, according to the 18-electron rule. This is consistent with the intermetallic separation of 2.580(1) $\AA$ in 8, which is ca. $0.06 \AA$ longer than the corresponding length of 2.528(2) $\AA$ in the 30-electron hydride $\left[\mathrm{Mo}_{2} \mathrm{Cp}_{2}(\mu-\mathrm{H})\left(\mu-\mathrm{PCy}_{2}\right)(\mathrm{CO})_{2}\right]$ [23], although still some $0.08 \AA$ shorter than the figure expected for a double bond (cf. 2.666(1) $\AA$ in the 32-electron complex $\left.\left[\mathrm{Mo}_{2} \mathrm{Cp}_{2}(\mu-\mathrm{CPh})(\mu-\mathrm{PCy})(\mathrm{CO})_{2}\right]\right)$ [28]. All of these structural parameters actually are very similar to those measured for the related homometallic complex $\left[\mathrm{Mo}_{2} \mathrm{Cp}_{2}\left(\mu-\kappa^{1}: \eta^{2}-\mathrm{CH}_{2} \mathrm{Ph}\right)(\mu-\mathrm{PCy})(\mathrm{CO})_{2}\right](\mathrm{Mo}-\mathrm{Mo}=2.580(1) \AA)$, a molecule for which the strength of the $\eta^{2}$-bonding interaction of the benzyl ligand has been estimated to be $89 \mathrm{~kJ} / \mathrm{mol}$, according to DFT calculations [29]. 


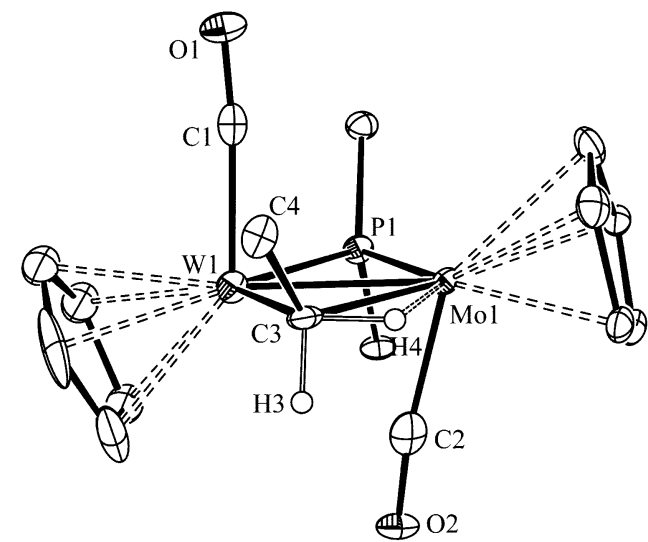

Figure 2. ORTEP diagram (30\% probability) of compound $\mathbf{8}$, with $\mathrm{Ph}$ and $\mathrm{Cy}$ groups (except their $\mathrm{C}^{1}$ atoms) and most $\mathrm{H}$ atoms omitted for clarity.

Table 3. Selected bond lengths $(\AA)$ and angles $\left(^{\circ}\right)$ for $\mathbf{8}$

\begin{tabular}{lcll}
\hline $\mathrm{W}(1)-\mathrm{Mo}(1)$ & $2.580(1)$ & $\mathrm{W}(1)-\mathrm{P}(1)-\mathrm{Mo}(1)$ & $65.4(1)$ \\
$\mathrm{W}(1)-\mathrm{P}(1)$ & $2.380(4)$ & $\mathrm{W}(1)-\mathrm{C}(3)-\mathrm{Mo}(1)$ & $67.2(5)$ \\
$\mathrm{Mo}(1)-\mathrm{P}(1)$ & $2.394(4)$ & $\mathrm{Mo}(1)-\mathrm{W}(1)-\mathrm{C}(1)$ & $86.7(4)$ \\
$\mathrm{W}(1)-\mathrm{C}(1)$ & $1.96(2)$ & $\mathrm{W}(1)-\mathrm{Mo}(1)-\mathrm{C}(2)$ & $73.8(5)$ \\
$\mathrm{Mo}(1)-\mathrm{C}(2)$ & $1.93(2)$ & $\mathrm{P}(1)-\mathrm{W}(1)-\mathrm{C}(1)$ & $85.4(5)$ \\
$\mathrm{W}(1)-\mathrm{C}(3)$ & $2.26(2)$ & $\mathrm{P}(1)-\mathrm{Mo}(1)-\mathrm{C}(2)$ & $81.9(5)$ \\
$\mathrm{Mo}(1)-\mathrm{C}(3)$ & $2.40(2)$ & $\mathrm{P}(1)-\mathrm{W}(1)-\mathrm{C}(3)$ & $116.5(4)$ \\
$\mathrm{C}(3)-\mathrm{H}(4)$ & $1.03(2)$ & $\mathrm{P}(1)-\mathrm{Mo}(1)-\mathrm{C}(3)$ & $110.9(4)$ \\
$\mathrm{Mo}(1)-\mathrm{H}(4)$ & $2.00(2)$ & $\mathrm{C}(1)-\mathrm{W}(1)-\mathrm{C}(3)$ & $90.0(6)$ \\
& & $\mathrm{C}(2)-\mathrm{Mo}(1)-\mathrm{C}(3)$ & $81.0(7)$ \\
\hline
\end{tabular}

Spectroscopic data in solution for $\mathbf{8}$ (Table 1 and Experimental section) are consistent with the structure found in the crystal, and also are comparable to those measured for its $\mathrm{Mo}_{2}$ and $\mathrm{W}_{2}$ analogues [29, 7a], so a detailed discussion is not needed. The retention in solution of the agostic coordination of the benzyl ligand in $\mathbf{8}$ is first indicated by the corresponding ${ }^{31} \mathrm{P}$ NMR data $\left(\delta_{\mathrm{P}} 112.2 \mathrm{ppm}, J_{\mathrm{PW}}=305 \mathrm{~Hz}\right)$, which are comparable to those of the iodide-bridged complex $\mathbf{3}$, thus suggesting an effective threeelectron contribution of the methyl ligand to the dimetal site. In addition, the involvement of one of the $\mathrm{C}-\mathrm{H}$ bonds in a tricentric interaction with a metal atom is denoted by the strong shielding of one of the methylenic ${ }^{1} \mathrm{H}$ resonances, which appears at $-2.02 \mathrm{ppm}$ (cf. $-1.35 \mathrm{ppm}$ and $-2.50 \mathrm{ppm}$ respectively for the corresponding $\mathrm{Mo}_{2}$ and $\mathrm{W}_{2}$ analogues).

\subsubsection{Solution structure of the agostic methyl complex 6.}

Spectroscopic IR and ${ }^{31} \mathrm{P}$ NMR data in solution for 6 (Table 1 and Experimental section) are similar to those of $\mathbf{8}$, thus suggesting that both compounds are isostructural. In the case of $\mathbf{6}$, however, there is no direct evidence for the agostic coordination of the methyl ligand, as the three $\mathrm{H}$ atoms remained equivalent on the NMR time scale at all temperatures, giving rise to a single resonance at ca. $-0.87 \mathrm{ppm}$ which remained 
unchanged down to $183 \mathrm{~K}$. The same observations were made previously for the corresponding homometallic analogues $\left(\delta_{\mathrm{H}}=-0.77\right.$ and $-1.18 \mathrm{ppm}$ respectively for the $\mathrm{Mo}_{2}$ and $\mathrm{W}_{2}$ complexes) [29, 7a], and they seem to be derived from the operation in all cases of a fast dynamic process involving the chemical exchange of all $\mathrm{H}$ atoms of the methyl ligand [29]. Actually, the averaged $\mathrm{C}-\mathrm{H}$ coupling of $122 \mathrm{~Hz}$ for $\mathbf{6}$ is somewhat lower than the corresponding value in the $\mathrm{Mo}_{2}$ complex [124 Hz], which might indicate a $\mathrm{C}-\mathrm{H} \cdots$ Mo interaction a bit stronger for the heterometallic complex.

To obtain further support for the agostic coordination of the methyl ligand in $\mathbf{6}$ and its selective $\kappa^{1}$-coordination to the tungsten atom (as found for the benzyl complex $\mathbf{8}$ ), we carried out DFT calculations on this molecule. We first note that, although models with $\kappa^{1}$-coordination to either Mo or $\mathrm{W}$ were attempted, only the latter rendered a minimum on the corresponding potential energy surface (Figure 3), with geometrical parameters comparable to those experimentally determined for the benzyl complex 8 . Therefore we conclude that there is a clear site preference of the alkyl ligands in these $\kappa^{1}: \eta^{2}$-bridged complexes, which favours $\kappa^{1}$-coordination specifically to the $\mathrm{W}$ atom, in line with the higher strength of $\mathrm{W}-\mathrm{C}$ bonds (when compared to Mo-C ones) usually found in organometallic complexes [25b, 30].

We also wondered whether an isomer bearing a terminal methyl ligand (that is, analogous to the terminal hydride isomer 5T) might be a sensible structure in this heterometallic system. Indeed we found that such a structure (6T-W, Figure 3$)$ is a true minimum with geometrical parameters comparable to those of $\mathbf{5 T}$, including a comparably short intermetallic length of $2.54 \AA$ consistent with the formulation of an intermetallic triple bond, as required on application of the 18-electron rule, and the presence of a linear semibridging carbonyl. The Gibbs free energy for 6T-W in the gas phase was only some $10 \mathrm{~kJ} / \mathrm{mol}$ higher than that of $\mathbf{6 T}$, so we cannot exclude its presence in the solutions of compound $\mathbf{6}$, even if in tiny amounts. As for the agostic isomer 6, the intermetallic length is expectedly longer $(2.594 \AA)$ and comparable to the experimental value measured in the benzyl complex 8 (2.580(1) $\AA$ ), because the $\eta^{2}$ coordination of the $\mathrm{C}-\mathrm{H}$ bond now provides additional electron density to the dimetal site, in detriment of the intermetallic interaction [29]. 

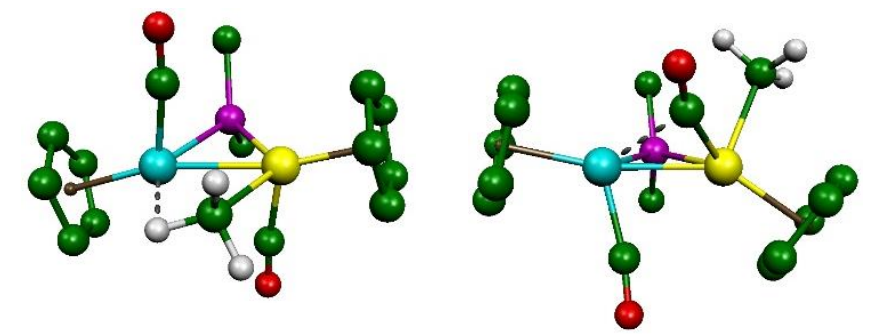

Figure 3. B3LYP-optimized structures for compound 6 (left) and an isomer having a terminal Me group bound to the $\mathrm{W}$ (yellow) atom (6T-W, right), with most $\mathrm{H}$ atoms and $\mathrm{Cy}$ groups (except $\mathrm{C}^{1}$ atoms) omitted for clarity. Relative Gibbs free energies at $295 \mathrm{~K}$ were 0 and $+10 \mathrm{~kJ} / \mathrm{mol}$ respectively. Selected bond lengths for $6(\AA)$ : $\mathrm{Mo}-\mathrm{W}=2.594 ; \mathrm{W}-\mathrm{CH}_{3}=2.282 ; \mathrm{Mo}-\mathrm{CH}_{3}=2.465 ; \mathrm{Mo} \cdots \mathrm{H}=2.206 ; \mathrm{C}-\mathrm{H} \cdots \mathrm{Mo}$ $=1.114 ; \mathrm{Mo}-\mathrm{P}=2.448 ; \mathrm{W}-\mathrm{P}=2.428$. Selected bond lengths for $6 \mathrm{~T}-\mathrm{W}: \mathrm{Mo}-\mathrm{W}=2.540 ; \mathrm{W}-\mathrm{CH}_{3}=$ $2.240 ; \mathrm{W}-\mathrm{CO}=1.979 ; \mathrm{Mo} \cdots \mathrm{CO}=2.398 ; \mathrm{H}_{2} \mathrm{C}-\mathrm{H}($ average $)=1.096 ; \mathrm{Mo}-\mathrm{P}=2.424 ; \mathrm{W}-\mathrm{P}=2.485$.

\subsection{Dehydrogenation of the agostic alkyl complexes 6 and 8.}

We have shown previously that photolysis of the benzyl-bridged homometallic complexes $\left[\mathrm{M}_{2} \mathrm{Cp}_{2}\left(\mu-\kappa^{1}: \eta^{2}-\mathrm{CH}_{2} \mathrm{Ph}\right)\left(\mu-\mathrm{PCy}_{2}\right)(\mathrm{CO})_{2}\right] \quad(\mathrm{M}=\mathrm{Mo}, \mathrm{W})$ results in decarbonylation and dehydrogenation of the benzyl group, to give the corresponding benzylidyne-bridged derivatives [28, 7a]. In contrast, photolysis of the related methylbridged complex $\left[\mathrm{Mo}_{2} \mathrm{Cp}_{2}\left(\mu-\kappa^{1}: \eta^{2}-\mathrm{CH}_{3}\right)\left(\mu-\mathrm{PCy}_{2}\right)(\mathrm{CO})_{2}\right]$ only resulted in decarbonylation of the dimetal substrate, to yield the 30-electron methyl-bridged derivative $\left[\mathrm{Mo}_{2} \mathrm{Cp}_{2}\left(\mu-\kappa^{1}: \eta^{2}-\mathrm{CH}_{3}\right)(\mu-\mathrm{PCy})(\mu-\mathrm{CO})\right]$ [31]. Recently, however, we found that the presence of the bulkier $\mathrm{P}^{t} \mathrm{Bu}_{2}$ group in these substrates somehow facilitates the dehydrogenation of bridging methyl ligands, so that the related complex $\left[\mathrm{Mo}_{2} \mathrm{Cp}_{2}(\mu-\right.$ $\left.\left.\kappa^{1}: \eta^{2}-\mathrm{CH}_{3}\right)\left(\mu-\mathrm{P}^{t} \mathrm{Bu}_{2}\right)(\mu-\mathrm{CO})\right]$ could be transformed easily into the corresponding methylidyne-bridged derivative upon gentle heating at $353 \mathrm{~K}$ [6]. It was thus of interest to examine the influence of the heterometallic MoW site on the dehydrogenation processes of the alkyl ligands present in complexes $\mathbf{6}$ and $\mathbf{8}$.

Irradiation of toluene solutions of $\mathbf{6}$ with visible-UV light at $288 \mathrm{~K}$ resulted in decarbonylation and dehydrogenation to give the corresponding methylidyne-bridged complex $\left[\mathrm{MoWCp}_{2}(\mu-\mathrm{CH})(\mu-\mathrm{PCy})(\mu-\mathrm{CO})\right]$ (9) as major product (Scheme 6), along with small amounts of compound $\mathbf{1}$, the latter obviously arising from some competing decomposition pathway. Since our previous studies on dehydrogenation reactions of the $\mathrm{P}^{t} \mathrm{Bu}_{2}$-bridged alkyl complexes revealed that the $\mathrm{C}-\mathrm{H}$ cleavage steps leading to dehydrogenation are thermal processes following photochemical decarbonylation [6], then the formation of $\mathbf{9}$ at room temperature suggests that the cooperative action of Mo and $\mathrm{W}$ atoms in these substrates greatly reduces the thermal barrier of the $\mathrm{C}-\mathrm{H}$ bond cleavage steps required for dehydrogenation of the methyl ligand. Unfortunately, we have no information concerning the photochemistry of the ditungsten complex 
$\left[\mathrm{W}_{2} \mathrm{Cp}_{2}\left(\mu-\kappa^{1}: \eta^{2}-\mathrm{CH}_{3}\right)\left(\mu-\mathrm{PCy}_{2}\right)(\mathrm{CO})_{2}\right] \quad$ [7a], so more conclusive evidence for heterometallic effects in these dehydrogenation processes is not possible at this stage.

According to the mentioned studies on $\mathrm{Mo}_{2}$ substrates, the thermal barrier for the $\mathrm{C}-\mathrm{H}$ bond cleavage steps leading to dehydrogenation are lower for the agostic benzyl ligands, when compared to the methyl ligands. Thus it was not surprising to find that photolysis of toluene solutions of the benzyl complex $\mathbf{8}$ at $288 \mathrm{~K}$ also resulted in easy dehydrogenation to yield the corresponding benzylidyne-bridged derivative $\left[\mathrm{MoWCp}_{2}(\mu-\mathrm{CPh})\left(\mu-\mathrm{PCy}_{2}\right)(\mu-\mathrm{CO})\right](\mathbf{1 0})$. In this case, however, small amounts of the bis(phosphanide) complex $\left[\mathrm{MoWCp}_{2}\left(\mu-\mathrm{PCy}_{2}\right)_{2}(\mu\right.$-CO)] (11) were formed as a side product (Scheme 6). The latter was identified by comparison of its IR and ${ }^{31} \mathrm{P}$ NMR data (Table 1) with those of related homometallic analogues $\left[\mathrm{M}_{2} \mathrm{Cp}_{2}\left(\mu \text { - } \mathrm{PR}_{2}\right)_{2}(\mu\right.$-CO)] $(\mathrm{M}=\mathrm{Mo}, \mathrm{W} ; \mathrm{R}=\mathrm{Cy}, \mathrm{Ph})[15,32]$, and no attempts to fully characterize it were made.

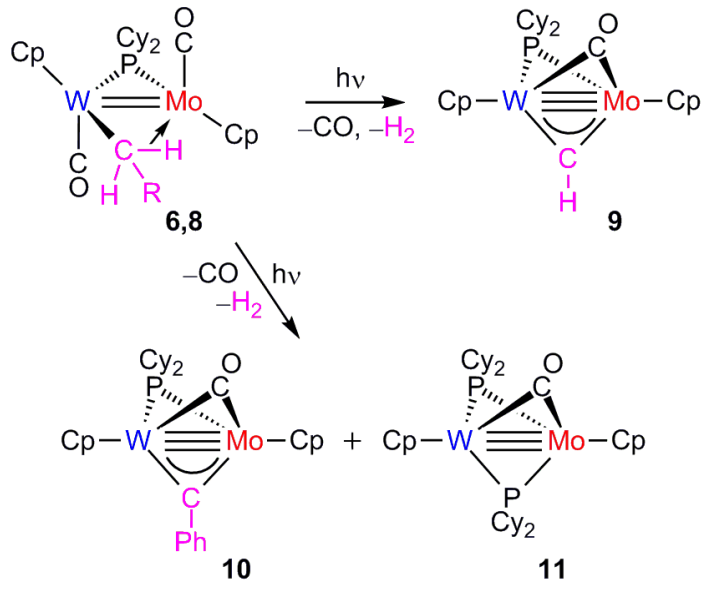

Scheme 6

\subsubsection{Structural characterization of carbyne-bridged complexes 7, 9 and 10.}

Spectroscopic data for the carbyne-bridged complexes 7, 9 and $\mathbf{1 0}$ are comparable to each other and also to those of related homometallic $\mathrm{Mo}_{2}$ and $\mathrm{W}_{2}$ complexes $[5-7,28]$, then requiring no detailed discussion. We note that this family of 30-electron complexes has been structurally characterized in several cases [8], whereby very short intermetallic lengths of ca. $2.47 \AA$ have been found in all cases. This is consistent with the triple bond to be proposed for these molecules on the basis of the 18-electron rule, more precisely described as following from a $\sigma^{2} \delta^{4}$ configuration, according to DFT calculations [33].

All these molecules are built from MCp fragments bridged by three different ligands: phosphanide, carbonyl and carbyne. The former gives rise to a strongly deshielded ${ }^{31} \mathrm{P}$ NMR resonance at ca. $195 \mathrm{ppm}$, characteristic of 30-electron complexes, which also displays high one-bond $\mathrm{P}-\mathrm{W}$ couplings of ca. $345 \mathrm{~Hz}$ denoting the low coordination number of the tungsten atom in these molecules. The carbyne ligand gives rise to diagnostic strongly deshielded ${ }^{13} \mathrm{C}$ NMR resonances (ca. 350-375 ppm), while the 
methylidyne ligand in 9 also accounts for a highly deshielded ${ }^{1} \mathrm{H}$ NMR resonance at $18.70 \mathrm{ppm}$ (cf. $16.74 \mathrm{ppm}$ for its crystallographically characterized $\mathrm{Mo}_{2}$ analogue) [28]. The bridging carbonyl ligand in these complexes gives rise to a ${ }^{13} \mathrm{C}$ resonance at ca. 300 ppm as expected, and the corresponding $\mathrm{C}-\mathrm{O}$ stretch for compounds $\mathbf{9}$ and $\mathbf{1 0}$ is observed at ca. $1661 \mathrm{~cm}^{-1}$, a frequency which is reduced by some $10 \mathrm{~cm}^{-1}$ in the methoxycarbyne complex $7\left(v_{\mathrm{CO}}=1653 \mathrm{~cm}^{-1}\right)$, a difference which can be attributed to the increased electron density at the dimetal site resulting from the $\pi$-bonding interaction present in the $\mathrm{C}-\mathrm{O}$ bond of alkoxycarbyne ligands [33].

\section{Conclusions}

As found for its homometallic analogues, the heterometallic anion $\mathbf{4}$ displays multisite reactivity, with nucleophilic sites located at the dimetal centre and the $\mathrm{O}$ atoms of the bridging carbonyls, as the reaction with MeI illustrates. In this respect, anion 4 displays a chemical behaviour intermediate between those observed for the $\mathrm{Mo}_{2}$ and $\mathrm{W}_{2}$ analogues. The hydride derivative of $\mathbf{4}$ displays two isomers in solution, as found for the $\mathrm{W}_{2}$ system, yet two additional structural effects can be appreciated in the heterometallic system: (a) a clear thermodynamic preference of the hydride ligand for terminal coordination at the $\mathrm{W}$ site (vs. Mo), estimated in some $20 \mathrm{~kJ} / \mathrm{mol}$ according to DFT calculations; and (b) a clear prevalence of the terminal isomer (T) vs. the hydridebridged one (B), when compared to either of the $\mathrm{Mo}_{2}$ or $\mathrm{W}_{2}$ homometallic systems, which can be then considered as a genuine heterometallic effect. A defined structural preference is also observed for the agostic methyl and benzyl derivatives of $\mathbf{4}$, which specifically are $\kappa^{1}$-bound to the $\mathrm{W}$ atom, while one of the $\mathrm{C}-\mathrm{H}$ bonds binds the Mo atom. The methyl ligand in the heterometallic complex is dehydrogenated much more easily than their $\mathrm{Mo}_{2}$ analogues, which suggests another genuine heterometallic effect, i.e. that the cooperative action of Mo and $\mathrm{W}$ atoms in these substrates greatly reduces the thermal barrier of the $\mathrm{C}-\mathrm{H}$ bond cleavage steps required for such dehydrogenation.

\section{Experimental}

All reactions and manipulations were carried out under a nitrogen atmosphere using standard Schlenk techniques. Solvents were purified according to literature procedures [34], and distilled under nitrogen prior to use. Petroleum ether refers to that fraction distilling in the range 338-343 $\mathrm{K}$, and the xylene used actually was a mixture of the corresponding $o$ - $m$ - and $p$-isomers. Complex $\left[\mathrm{W}_{2} \mathrm{Cp}_{2}(\mathrm{CO})_{6}\right]\left(\mathrm{Cp}=\eta^{5}-\mathrm{C}_{5} \mathrm{H}_{5}\right)$ was prepared as described previously [35]. All other reagents were obtained from the usual commercial suppliers and used as received. Photochemical experiments were performed using jacketed Schlenk tubes, cooled by tap water (ca. 288 K). A 400 W mercury lamp placed ca. $1 \mathrm{~cm}$ away from the Schlenk tube was used for all experiments. 
Chromatographic separations were carried out using jacketed columns refrigerated by tap water (ca. $288 \mathrm{~K}$ ) or by a closed 2-propanol circuit kept at the desired temperature with a cryostat. Commercial aluminium oxide (activity I, 70-290 mesh) was degassed under vacuum prior to use. The latter was mixed under nitrogen with the appropriate amount of water to reach activity IV. IR stretching frequencies of CO ligands were measured in solution using $\mathrm{CaF}_{2}$ windows, are referred to as $v(\mathrm{CO})$, and are given in $\mathrm{cm}^{-1}$. Nuclear magnetic resonance (NMR) spectra were routinely recorded at room temperature in $\mathrm{CD}_{2} \mathrm{Cl}_{2}$ solutions unless otherwise stated. Chemical shifts $(\delta)$ are given in ppm, relative to internal tetramethylsilane $\left({ }^{1} \mathrm{H}\right.$ and $\left.{ }^{13} \mathrm{C}\right)$, or external $85 \%$ aqueous $\mathrm{H}_{3} \mathrm{PO}_{4}$ solutions $\left({ }^{31} \mathrm{P}\right)$. Coupling constants $(J)$ are given in hertz.

\subsection{Preparation of $\left[\mathrm{MoWCp} 2(\mu-\mathrm{H})\left(\mu-\mathrm{PC} y_{2}\right)(\mathrm{CO})_{4}\right](\mathbf{1})$.}

Neat $\mathrm{PHCy}_{2}(500 \mu \mathrm{L}, 2.280 \mathrm{mmol})$ was added to a xylene solution (3 mL) of complexes $\left[\mathrm{Mo}_{2} \mathrm{Cp}_{2}(\mathrm{CO})_{6}\right](0.540 \mathrm{~g}, 1.102 \mathrm{mmol})$ and $\left[\mathrm{W}_{2} \mathrm{Cp}_{2}(\mathrm{CO})_{6}\right](0.730 \mathrm{~g}, 1.096$ mmol) in a Schlenk tube equipped with a Young's valve. After closing the valve, the mixture was stirred at $453 \mathrm{~K}$ for $6 \mathrm{~h}$ to give an orange solution. The solvent was then removed under vacuum, the residue extracted with dichloromethane/petroleum ether $(1 / 5)$ and the extracts chromatographed through a silica gel column (230-400 mesh) at $253 \mathrm{~K}$. Elution with dichloromethane/petroleum ether (1/5) gave an orange fraction yielding, after removal of solvents, the known complex $\left[\mathrm{Mo}_{2} \mathrm{Cp}_{2}(\mu-\mathrm{H})(\mu-\mathrm{PCy})(\mathrm{CO})_{4}\right]$ as an orange solid $(0.090 \mathrm{~g}, 13 \%)$. Elution with dichloromethane/petroleum ether $(1 / 3)$ gave two more orange fractions analogously yielding, respectively, compound 1 ( 0.460 $\mathrm{g}, 29 \%)$ and the known complex $\left[\mathrm{W}_{2} \mathrm{Cp}_{2}(\mu-\mathrm{H})\left(\mu-\mathrm{PCy}_{2}\right)(\mathrm{CO})_{4}\right](0.080 \mathrm{~g}, 10 \%)$, as orange solids. Data for compound 1: Anal. Calc. for $\mathrm{C}_{26} \mathrm{H}_{33} \mathrm{MoO}_{4} \mathrm{PW}$ : C, 43.35; H, 4.62. Found: $\mathrm{C}, 43.08 ; \mathrm{H}, 4.57 .{ }^{1} \mathrm{H}$ NMR (400.13 MHz, $\left.\mathrm{C}_{6} \mathrm{D}_{6}\right): \delta 5.04,5.02(2 \mathrm{~s}, 2$ x $5 \mathrm{H}$, Cp), 2.89 (m, 1H, Cy), 2.77 (m, 1H, Cy), 2.51, 1.78 (2m, 2 x 2H, Cy), 1.62 (m, 4H, Cy), $1.32(\mathrm{~m}, 8 \mathrm{H}, \mathrm{Cy}), 0.90,0.15(2 \mathrm{~m}, 2 \mathrm{x} 2 \mathrm{H}, \mathrm{Cy}),-14.56\left(\mathrm{~d}, J_{\mathrm{HP}}=30, J_{\mathrm{HW}}=40,1 \mathrm{H}, \mu-\mathrm{H}\right)$. ${ }^{13} \mathrm{C}\left\{{ }^{1} \mathrm{H}\right\}$ NMR $\left(100.63 \mathrm{MHz}, \mathrm{C}_{6} \mathrm{D}_{6}\right): \delta 242.4\left(\mathrm{~d}, J_{\mathrm{CP}}=27, \mathrm{MoCO}\right), 236.4$ (s, MoCO), $235.1\left(\mathrm{~d}, J_{\mathrm{CP}}=19, \mathrm{WCO}\right), 222.9$ (s, WCO), 90.3 (s, $\left.J_{\mathrm{CW}}=49, \mathrm{WCp}\right), 88.5$ (s, MoCp), $41.1\left[\mathrm{~d}, J_{\mathrm{CP}}=20,2 \mathrm{C}^{1}(\mathrm{Cy})\right], 32.4,32.0\left[2 \mathrm{~s}, \mathrm{C}^{2}(\mathrm{Cy})\right], 30.7$ [s, 2C $\left.\mathrm{C}^{2}(\mathrm{Cy})\right], 28.3,28.1$ [2d, $\left.J_{\mathrm{CP}}=10, \mathrm{C}^{3}(\mathrm{Cy})\right], 27.4\left[\mathrm{~d}, J_{\mathrm{CP}}=14, \mathrm{C}^{3}(\mathrm{Cy})\right], 27.3\left[\mathrm{~d}, J_{\mathrm{CP}}=13, \mathrm{C}^{3}(\mathrm{Cy})\right], 27.2[\mathrm{~s}$, $\left.2 \mathrm{C}^{4}(\mathrm{Cy})\right]$.

\subsection{Preparation of $\left[\mathrm{MoWCp} 2\left(\mu-P C y_{2}\right)(C O)_{4}\right]\left(B F_{4}\right)(2)$.}

Neat $\mathrm{HBF}_{4} \cdot \mathrm{OEt}_{2}(90 \mu \mathrm{L}, 0.656 \mathrm{mmol})$ was added to a dichloromethane solution (20 $\mathrm{mL})$ of compound $1(0.350 \mathrm{~g}, 0.486 \mathrm{mmol})$, and the mixture was stirred at room temperature for $30 \mathrm{~min}$ to give a dark green solution which was filtered through diatomaceous earth. The solvent was then removed from the filtrate under vacuum, and 
the residue was washed with diethyl ether $(4 \mathrm{x} 8 \mathrm{~mL})$ to give a dark green powder containing essentially pure compound 2 , which was used in the preparation of compound 3 without further purification. ${ }^{1} \mathrm{H}$ NMR (400.13 $\mathrm{MHz}, \mathrm{CD}_{2} \mathrm{Cl}_{2}$ ): $\delta 6.03,5.86$ (2s, 2 x 5H, Cp), 2.52-0.53 (m, 22H, Cy).

\subsection{Preparation of $\left[\mathrm{MoWCp} 2(\mu-\mathrm{I})\left(\mu-\mathrm{PC} y_{2}\right)(\mathrm{CO})_{2}\right](3)$.}

Solid NaI (0.300 g, $3.336 \mathrm{mmol})$ was added to a 1,2-dichloroethane solution (15 mL) of the crude compound 2 prepared as described in section 4.2 (ca. $0.486 \mathrm{mmol}$ ), and the mixture was refluxed for $90 \mathrm{~min}$ to give a green solution which was filtered using a canula. Removal of solvent from the filtrate gave a green solid containing essentially pure, air-sensitive compound 3 , which was used in the preparation of complex 4 without further purification. ${ }^{1} \mathrm{H}$ NMR (300.13 MHz, $\left.\mathrm{C}_{6} \mathrm{D}_{6}\right): \delta 5.01,4.96$ (2s, 2 x 5H, Cp), 2.401.07 (m, 22H, Cy).

\subsection{Preparation of tetrahydrofuran suspensions of $\mathrm{Na}\left[\mathrm{MoWCp} 2\left(\mu-\mathrm{PC} y_{2}\right)(\mu-\mathrm{CO})_{2}\right]$ (4-} $\mathrm{Na}$.

Sodium amalgam (ca. $1 \mathrm{~mL}$ of a $0.5 \%$ amalgam, $3 \mathrm{mmol}$ ) was added to a tetrahydrofuran solution $(15 \mathrm{~mL})$ of the crude compound 3 prepared as described in section 4.3 (ca. $0.486 \mathrm{mmol}$ ), and the mixture was stirred for $20 \mathrm{~min}$ to give an orange suspension of the very air-sensitive compound 4-Na. This suspension was transferred with a cannula to an empty Schlenk tube, to remove the excess amalgam, and was then ready for further use.

\subsection{Preparation of $\left[\mathrm{MoWCp} 2(\mathrm{H})\left(\mu-\mathrm{PC} y_{2}\right)(\mathrm{CO})_{2}\right](5)$.}

Solid $\left(\mathrm{NH}_{4}\right) \mathrm{PF}_{6}(0.120 \mathrm{~g}, 0.736 \mathrm{mmol})$ was added to a tetrahydrofuran suspension (15 mL) of compound 4-Na (ca. $0.486 \mathrm{mmol}$ ) prepared as described in section 4.4, and the mixture was stirred for $5 \mathrm{~min}$ to give a purple solution. The solvent was then removed under vacuum, the residue extracted with dichloromethane/petroleum ether $(1 / 5)$, and the extracts were filtered through diatomaceous earth. After removal of solvents from the filtrate, the residue was dissolved in dichloromethane/petroleum ether $(1 / 5)$ and chromatographed on alumina at 253 K. Elution with dichloromethane/petroleum ether (1/3) gave a green band yielding, after removal of solvents, compound 5 as a purple solid $(0.260 \mathrm{~g}, 80 \%)$. This compound was shown by NMR to display in solution two interconverting isomers ( $\mathbf{B}$ and $\mathbf{T}$, see text) with the equilibrium 5T/5B ratio being solvent- and temperature-dependent, with ${ }^{1} \mathrm{H}$ NMRmeasured ratios of $1.8\left(\mathrm{CD}_{2} \mathrm{Cl}_{2}, 203 \mathrm{~K}\right), 2.5\left(\mathrm{CD}_{2} \mathrm{Cl}_{2}, 183 \mathrm{~K}\right)$ and 0.6 (toluene- $d_{8}, 183$ K). Anal. Calc. for $\mathrm{C}_{25} \mathrm{H}_{35} \mathrm{Cl}_{2} \mathrm{MoO}_{2} \mathrm{PW}\left(\mathbf{5} \cdot \mathrm{CH}_{2} \mathrm{Cl}_{2}\right)$ : C, 40.08; H, 4.71. Found: C, 39.71; 
$\mathrm{H}$, 5.23. ${ }^{1} \mathrm{H}$ NMR (400.13 MHz, $\left.\mathrm{CD}_{2} \mathrm{Cl}_{2}, 293 \mathrm{~K}\right): \delta 5.25,5.18(2 \mathrm{~s}, 2$ x 5H, Cp), 2.521.00 (m, 22H, Cy), -3.92 (s, br, 1H, M-H). ${ }^{1} \mathrm{H}$ NMR (400.13 MHz, $\mathrm{CD}_{2} \mathrm{Cl}_{2}, 183 \mathrm{~K}$ ): Isomer 5T: $\delta 5.43,5.31(2 \mathrm{~s}, 2 \times 5 \mathrm{H}, \mathrm{Cp}),-1.46\left(\mathrm{~d}, J_{\mathrm{HP}}=32, J_{\mathrm{HW}}=70, \mathrm{~W}-\mathrm{H}\right)$. Isomer 5B: $\delta 5.24,5.19(2 \mathrm{~s}, 2 \times 5 \mathrm{H}, \mathrm{Cp}),-6.41\left(\mathrm{~d}, J_{\mathrm{HP}}=3, J_{\mathrm{HW}}=118, \mu-\mathrm{H}\right) .{ }^{13} \mathrm{C}\left\{{ }^{1} \mathrm{H}\right\} \mathrm{NMR}$ $\left(100.63 \mathrm{MHz}, \mathrm{CD}_{2} \mathrm{Cl}_{2}, 183 \mathrm{~K}\right): \delta 276.2$ (s, WCO, 5T), $251.0\left(\mathrm{~d}, J_{\mathrm{CP}}=7\right.$, MoCO, 5T), $246.0\left(\mathrm{~d}, J_{\mathrm{CP}}=10, \mathrm{MoCO}\right.$, 5B), 235.8 (s, WCO, 5B), 90.7, 90.6 (2s, Cp, 5T), 87.9, 87.5 $(2 \mathrm{~s}, \mathrm{Cp}, \mathbf{5 B}), 45.2,43.3$ [2d, $\left.J_{\mathrm{CP}}=21, \mathrm{C}^{1}(\mathrm{Cy}), \mathbf{5 T}\right], 36.0\left[\mathrm{~d}, J_{\mathrm{CP}}=6, \mathrm{C}^{2}(\mathrm{Cy}), \mathbf{5 B}\right], 34.9$,

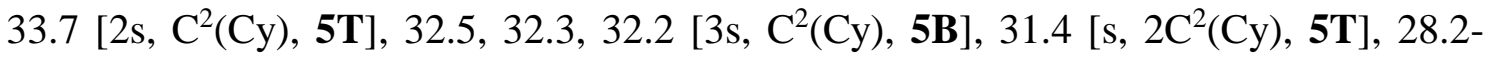
$26.7\left[\mathrm{~m}, 4 \mathrm{C}^{3}(\mathrm{Cy}), \mathbf{5 T}\right.$ and $\left.\mathbf{5 B}\right], 26.3,26.1\left[2 \mathrm{~s}, \mathrm{C}^{4}(\mathrm{Cy}), \mathbf{5 T}\right.$ and $\left.\mathbf{5 B}\right]$; the $\mathrm{C}^{1}(\mathrm{Cy})$ resonances of the minor isomer $\mathbf{5 B}$ could not be identified in this spectrum.

\subsection{Reaction of 4-Na with MeI.}

Neat MeI (40 $\mu \mathrm{L}, 0.643 \mathrm{mmol})$ was added to a tetrahydrofuran suspension $(8 \mathrm{~mL})$ of compound 4-Na (ca. $0.120 \mathrm{mmol}$ ) prepared as described in section 4.4, and the mixture was stirred at room temperature for $24 \mathrm{~h}$ to give a brown solution. The solvent was then removed under vacuum, the residue extracted with dichloromethane/petroleum ether $(1 / 5)$, and the extracts were chromatographed on alumina at $253 \mathrm{~K}$. Elution with dichloromethane/petroleum ether (1/3) gave a brown fraction yielding, after removal of solvents, complex $\left[\mathrm{MoWCp}_{2}\left(\mu-\kappa^{1}: \eta^{2}-\mathrm{CH}_{3}\right)(\mu-\mathrm{PCy})(\mathrm{CO})_{2}\right](6)$ as a brown solid $(0.045$ $\mathrm{g}, 55 \%)$. Elution with neat dichloromethane gave another brown fraction analogously yielding complex $\left[\mathrm{MoWCp}_{2}(\mu\right.$-COMe $\left.)(\mu-\mathrm{PCy})(\mu-\mathrm{CO})\right](7)$ as a brown solid $(0.010 \mathrm{~g}$, 12\%). Data for compound 6: Anal. Calc. for $\mathrm{C}_{25} \mathrm{H}_{35} \mathrm{MoO}_{2} \mathrm{PW}$ : C, 44.27; H, 5.20. Found: $\mathrm{C}$, 44.37; H, 5.59. ${ }^{1} \mathrm{H}$ NMR (400.13 MHz, $\left.\mathrm{CD}_{2} \mathrm{Cl}_{2}, 233 \mathrm{~K}\right): \delta 5.29,5.28(2 \mathrm{~s}, 2$ x $5 \mathrm{H}$, $\mathrm{Cp}), 2.28-1.06(\mathrm{~m}, 22 \mathrm{H}, \mathrm{Cy}),-0.87\left(\mathrm{~d}, J_{\mathrm{HP}}=2, J_{\mathrm{HC}}=122,3 \mathrm{H}, \mu-\mathrm{CH}_{3}\right) .{ }^{13} \mathrm{C}\left\{{ }^{1} \mathrm{H}\right\} \mathrm{NMR}$ $\left(100.63 \mathrm{MHz}, \mathrm{CD}_{2} \mathrm{Cl}_{2}, 233 \mathrm{~K}\right): \delta 245.9\left(\mathrm{~d}, J_{\mathrm{CP}}=12, \mathrm{MoCO}\right), 241.4\left(\mathrm{~d}, J_{\mathrm{CP}}=8, \mathrm{WCO}\right)$, 88.5, 88.1 (2s, Cp), $47.0\left[\mathrm{~d}, J_{\mathrm{CP}}=22,2 \mathrm{C}^{1}(\mathrm{Cy})\right], 34.0,33.9\left[2 \mathrm{~d}, J_{\mathrm{CP}}=3, \mathrm{C}^{2}(\mathrm{Cy})\right], 32.7$, $32.6\left[2 \mathrm{~s}, \mathrm{C}^{2}(\mathrm{Cy})\right], 28.2\left[\mathrm{~d}, J_{\mathrm{CP}}=12,2 \mathrm{C}^{3}(\mathrm{Cy})\right], 28.0,27.8\left[2 \mathrm{~d}, J_{\mathrm{CP}}=11, \mathrm{C}^{3}(\mathrm{Cy})\right], 26.4$, $26.3\left[2 \mathrm{~s}, \mathrm{C}^{4}(\mathrm{Cy})\right],-44.6\left(\mathrm{~s}, \mu-\mathrm{CH}_{3}\right)$.

\subsection{Preparation of [MoWCp $\left.2(\mu-C O M e)\left(\mu-P C y_{2}\right)(\mu-C O)\right](7)$.}

Neat $\mathrm{Me}_{2} \mathrm{SO}_{4}$ (30 $\mu \mathrm{L}, 0.317 \mathrm{mmol}$ ) was added to a tetrahydrofuran suspension (4 $\mathrm{mL}$ ) of compound 4-Na (ca. $0.060 \mathrm{mmol}$ ) prepared as described in section 4.4, and the mixture was stirred at room temperature for $18 \mathrm{~h}$ to give a brown solution. The solvent was then removed under vacuum, the residue extracted with dichloromethane/petroleum ether (1/7), and the extracts were chromatographed on alumina at $288 \mathrm{~K}$. Elution with dichloromethane/petroleum ether (1/1) gave a brown fraction yielding, after removal of solvents, compound 7 as a brown solid $(0.035 \mathrm{~g}, 86 \%)$. Anal. Calc. for $\mathrm{C}_{25} \mathrm{H}_{35} \mathrm{MoO}_{2} \mathrm{PW}$ : C, 44.27; H, 5.20. Found: C, 44.68; H, 5.66. ${ }^{1} \mathrm{H}$ NMR (400.13 MHz, $\left.\mathrm{C}_{6} \mathrm{D}_{6}\right): \delta 5.82,5.72$ 
(2s, 2 x 5H, Cp), 3.33 (s, 3H, OMe), 1.92-0.38 (m, 22H, Cy). ${ }^{13} \mathrm{C}\left\{{ }^{1} \mathrm{H}\right\}$ NMR (100.63 $\left.\mathrm{MHz}, \mathrm{C}_{6} \mathrm{D}_{6}\right): \delta 348.3\left(\mathrm{~d}, J_{\mathrm{CP}}=11, \mu-C \mathrm{OMe}\right.$ ), 298.2 (s, br, $\mu$-CO), 93.9, 93.1 (2s, Cp), $65.3(\mathrm{~s}, \mathrm{OMe}), 42.6,41.7$ [2d, $\left.J_{\mathrm{CP}}=21, \mathrm{C}^{1}(\mathrm{Cy})\right], 34.4,34.3,33.9,33.6$ [4s, $\left.\mathrm{C}^{2}(\mathrm{Cy})\right]$, 27.8-27.4 [m, $\left.4 \mathrm{C}^{3}(\mathrm{Cy})\right], 26.6,26.4\left[2 \mathrm{~s}, \mathrm{C}^{4}(\mathrm{Cy})\right]$.

\subsection{Preparation of [MoWCp $\left.2\left(\mu-\kappa^{l}: \eta^{2}-\mathrm{CH}_{2} \mathrm{Ph}\right)\left(\mu-\mathrm{PC} y_{2}\right)(\mathrm{CO})_{2}\right](8)$.}

Neat benzyl chloride (100 $\mu \mathrm{L}, 1.304 \mathrm{mmol})$ was added to a tetrahydrofuran suspension $(10 \mathrm{~mL})$ of compound 4-Na (ca. $0.090 \mathrm{mmol}$ ) prepared as described in section 4.4, and the mixture was stirred in the dark at room temperature for $5 \mathrm{~d}$ to give a brown solution. The solvent was then removed under vacuum, the residue extracted with dichloromethane, and the extracts filtered through diatomaceous earth. After removal of solvent from the filtrate, the residue was now extracted with dichloromethane/petroleum ether (1/7), and the extracts were chromatographed on alumina at $288 \mathrm{~K}$. Elution with dichloromethane/petroleum ether (1/5) gave a brown fraction yielding, after removal of solvents, compound $\mathbf{8}$ as a brown solid $(0.050 \mathrm{~g}$, $74 \%$ ). The crystals used in the X-ray study were grown by the slow diffusion of layers of toluene and petroleum ether into a concentrated dichloromethane solution of the complex at $253 \mathrm{~K}$. Anal. Calc. for $\mathrm{C}_{31} \mathrm{H}_{39} \mathrm{MoO}_{2} \mathrm{PW}$ : C, 49.36; H, 5.21. Found: C, 49.09; $\mathrm{H}$, 5.33. ${ }^{1} \mathrm{H}$ NMR (300.13 MHz, $\mathrm{CD}_{2} \mathrm{Cl}_{2}$ ): $\delta 7.18$ [false t, $J_{\mathrm{HH}}=8,2 \mathrm{H}, \mathrm{H}^{3}(\mathrm{Ph})$ ], 6.96 [false d, $\left.J_{\mathrm{HH}}=7,2 \mathrm{H}, \mathrm{H}^{2}(\mathrm{Ph})\right], 6.86\left[\mathrm{t}, J_{\mathrm{HH}}=7,1 \mathrm{H}, \mathrm{H}^{4}(\mathrm{Ph})\right], 5.42,5.07(2 \mathrm{~s}, 2 \mathrm{x} 5 \mathrm{H}, \mathrm{Cp})$, $2.47\left(\mathrm{~d}, J_{\mathrm{HH}}=15,1 \mathrm{H}, \mu-\mathrm{CH}_{2} \mathrm{Ph}\right), 2.37-0.98(\mathrm{~m}, 22 \mathrm{H}, \mathrm{Cy}),-2.02\left(\mathrm{~d}, J_{\mathrm{HH}}=15,1 \mathrm{H}, \mu-\right.$ $\left.\mathrm{CH}_{2} \mathrm{Ph}\right) .{ }^{13} \mathrm{C}\left\{{ }^{1} \mathrm{H}\right\}$ NMR (74.48 MHz, $\left.\mathrm{CD}_{2} \mathrm{Cl}_{2}\right): \delta 243.8\left(\mathrm{~d}, J_{\mathrm{CP}}=11, \mathrm{MoCO}\right), 240.3(\mathrm{~d}$, $\left.J_{\mathrm{CP}}=8, \mathrm{WCO}\right), 155.3\left[\mathrm{~s}, \mathrm{C}^{1}(\mathrm{Ph})\right], 127.6,127.2\left[2 \mathrm{~s}, \mathrm{C}^{2,3}(\mathrm{Ph})\right], 122.1$ [s, $\left.\mathrm{C}^{4}(\mathrm{Ph})\right], 89.0$, $87.9(2 \mathrm{~s}, \mathrm{Cp}), 49.8\left[\mathrm{~d}, J_{\mathrm{CP}}=23, \mathrm{C}^{1}(\mathrm{Cy})\right], 47.5\left[\mathrm{~d}, J_{\mathrm{CP}}=22, \mathrm{C}^{1}(\mathrm{Cy})\right], 34.3,34.2\left[2 \mathrm{~d}, J_{\mathrm{CP}}\right.$ $\left.=3, \mathrm{C}^{2}(\mathrm{Cy})\right], 33.3,33.1\left[2 \mathrm{~s}, \mathrm{C}^{2}(\mathrm{Cy})\right], 28.4\left[\mathrm{~d}, J_{\mathrm{CP}}=12,2 \mathrm{C}^{3}(\mathrm{Cy})\right], 28.3\left[\mathrm{~d}, J_{\mathrm{CP}}=11\right.$, $\left.\mathrm{C}^{3}(\mathrm{Cy})\right], 28.2\left[\mathrm{~d}, J_{\mathrm{CP}}=10, \mathrm{C}^{3}(\mathrm{Cy})\right], 26.6\left[\mathrm{~s}, 2 \mathrm{C}^{4}(\mathrm{Cy})\right],-3.9\left(\mathrm{~s}, 1 \mathrm{H}, \mu-\mathrm{CH}_{2} \mathrm{Ph}\right)$.

\subsection{Preparation of $\left[\mathrm{MoWCp} 2(\mu-\mathrm{CH})\left(\mu-\mathrm{PC} y_{2}\right)(\mu-\mathrm{CO})\right]$ (9).}

A toluene solution $(5 \mathrm{~mL})$ of compound $6(0.030 \mathrm{~g}, 0.044 \mathrm{mmol})$ was irradiated with visible-UV light at $288 \mathrm{~K}$ for $30 \mathrm{~min}$, with a gentle nitrogen purge, to give a brownpurple solution containing compound 9 as major product, along with significant amounts of compound 1. The solvent was then removed under vacuum, the residue extracted with dichloromethane/petroleum ether (1/5), and the extracts were chromatographed on alumina at $253 \mathrm{~K}$. Elution with dichloromethane/petroleum ether (1/1) gave a purple fraction yielding, after removal of solvents, compound $\mathbf{9}$ as a red solid (0.020 g, 70\%). Anal. Calc. for $\mathrm{C}_{24} \mathrm{H}_{33} \mathrm{MoO}_{2} \mathrm{PW}$ : C, 44.47; H, 5.13. Found: C, 44.74; H, 5.55. ${ }^{1} \mathrm{H}$ NMR (400.13 MHz, $\mathrm{C}_{6} \mathrm{D}_{6}$ ): $\delta 18.70$ (s, $\left.J_{\mathrm{HW}}=20,1 \mathrm{H}, \mu-\mathrm{CH}\right), 5.84$, 5.75 (2s, 2 x 5H, Cp), 1.83-0.63 (m, 19H, Cy), 0.48-0.33 (m, 3H, Cy). ${ }^{13} \mathrm{C}\left\{{ }^{1} \mathrm{H}\right\} \mathrm{NMR}$ 
(100.63 MHz, $\left.\mathrm{C}_{6} \mathrm{D}_{6}\right): \delta 369.4\left(\mathrm{~d}, J_{\mathrm{CP}}=11, \mu-\mathrm{CH}\right), 296.6\left(\mathrm{~d}, J_{\mathrm{CP}}=5, \mu-\mathrm{CO}\right), 94.6,93.8$ (2s, Cp), $42.6\left[\mathrm{~d}, J_{\mathrm{CP}}=22, \mathrm{C}^{1}(\mathrm{Cy})\right], 40.4\left[\mathrm{~d}, J_{\mathrm{CP}}=20, \mathrm{C}^{1}(\mathrm{Cy})\right], 34.1,34.0,33.7,33.1$ [4s, $\left.\mathrm{C}^{2}(\mathrm{Cy})\right], 27.5\left[\mathrm{~d}, J_{\mathrm{CP}}=11, \mathrm{C}^{3}(\mathrm{Cy})\right], 27.4\left[\mathrm{~d}, J_{\mathrm{CP}}=12,3 \mathrm{C}^{3}(\mathrm{Cy})\right], 26.4,26.1[2 \mathrm{~s}$, $\left.\mathrm{C}^{4}(\mathrm{Cy})\right]$.

\subsection{Photolysis of the benzyl complex 8.}

A toluene solution $(6 \mathrm{~mL})$ of compound $8(0.030 \mathrm{~g}, 0.040 \mathrm{mmol})$ was irradiated with visible-UV light at $288 \mathrm{~K}$ for $15 \mathrm{~min}$, with a gentle nitrogen purge, to give a reddish brown solution containing complex $\left[\mathrm{MoWCp}_{2}(\mu-\mathrm{CPh})(\mu-\mathrm{PCy})(\mu-\mathrm{CO})\right](\mathbf{1 0})$ as major product, along with smaller amounts of $\left[\mathrm{MoWCp}_{2}\left(\mu-\mathrm{PCy}_{2}\right)_{2}(\mu-\mathrm{CO})\right](\mathbf{1 1})$. The solvent was then removed under vacuum, the residue extracted with dichloromethane/petroleum ether (1/7), and the extracts were chromatographed on alumina at $288 \mathrm{~K}$. Elution with dichloromethane/petroleum ether (1/3) gave a brown fraction yielding, after removal of solvents, compound $\mathbf{1 0}$ as a brown solid (0.018 g, 62\%). Elution with neat dichloromethane gave a pink fraction yielding analogously complex $\mathbf{1 1}$ as a pink solid (0.006 g, 17\%). Data for compound 10: Anal. Calc. for $\mathrm{C}_{30} \mathrm{H}_{37} \mathrm{MoOPW}$ : C, 49.74; H, 5.15. Found: C, 49.52; $\mathrm{H}, 5.00 .{ }^{1} \mathrm{H}$ NMR $\left(400.13 \mathrm{MHz}, \mathrm{CD}_{2} \mathrm{Cl}_{2}\right): \delta 7.12$ [false t, $J_{\mathrm{HH}}=$ $\left.8,2 \mathrm{H}, \mathrm{H}^{3}(\mathrm{Ph})\right], 6.99\left[\mathrm{t}, J_{\mathrm{HH}}=7,1 \mathrm{H}, \mathrm{H}^{4}(\mathrm{Ph})\right], 6.57$ [false d, $J_{\mathrm{HH}}=7,2 \mathrm{H}, \mathrm{H}^{2}(\mathrm{Ph})$ ], 5.94, 5.87 (2s, 2 x 5H, Cp), 1.98-0.93 (m, 17H, Cy), 0.68-0.48 (m, 5H, Cy). ${ }^{13} \mathrm{C}\left\{{ }^{1} \mathrm{H}\right\} \mathrm{NMR}$ $\left(100.63 \mathrm{MHz}, \mathrm{CD}_{2} \mathrm{Cl}_{2}\right): \delta 375.0\left(\mathrm{~d}, J_{\mathrm{CP}}=11, \mu-C \mathrm{Ph}\right), 302.4\left(\mathrm{~d}, J_{\mathrm{CP}}=6, \mu-\mathrm{CO}\right), 166.5$ [s, $\left.\mathrm{C}^{1}(\mathrm{Ph})\right], 127.8$ [s, $\left.\mathrm{C}^{3}(\mathrm{Ph})\right], 124.1$ [s, $\left.\mathrm{C}^{4}(\mathrm{Ph})\right], 121.0$ [s, $\left.\mathrm{C}^{2}(\mathrm{Ph})\right], 96.0,95.2(2 \mathrm{~s}, \mathrm{Cp}), 43.6$ $\left[\mathrm{d}, J_{\mathrm{CP}}=23, \mathrm{C}^{1}(\mathrm{Cy})\right], 42.4\left[\mathrm{~d}, J_{\mathrm{CP}}=21, \mathrm{C}^{1}(\mathrm{Cy})\right], 34.2,34.1,33.6,33.3\left[4 \mathrm{~s}, \mathrm{C}^{2}(\mathrm{Cy})\right]$, $27.5\left[\mathrm{~d}, J_{\mathrm{CP}}=12, \mathrm{C}^{3}(\mathrm{Cy})\right], 27.5\left[\mathrm{~d}, J_{\mathrm{CP}}=12,3 \mathrm{C}^{3}(\mathrm{Cy})\right], 26.4,26.3\left[2 \mathrm{~s}, \mathrm{C}^{4}(\mathrm{Cy})\right]$. Data for compound 11: ${ }^{1} \mathrm{H}$ NMR (400.13 MHz, $\left.\mathrm{C}_{6} \mathrm{D}_{6}\right): \delta 5.75,5.64(2 \mathrm{~s}, 2$ x $5 \mathrm{H}, \mathrm{Cp}), 2.02-0.81$ (m, 44H, Cy).

\subsection{X-ray data collection, structure determination and refinements for compound 8 .}

X-ray intensity data were collected at ca. $140 \mathrm{~K}$ on an Oxford Diffraction Xcalibur Nova single crystal diffractometer, using $\mathrm{Cu} \mathrm{K} \alpha$ radiation. Images were collected at a $63 \mathrm{~mm}$ fixed crystal-detector distance using the oscillation method, with $1^{\circ}$ oscillation and variable exposure time per image. Data collection strategy was calculated with the program CrysAlis Pro CCD [36], and data reduction and cell refinement was performed with the program CrysAlis Pro RED [36]. An empirical absorption correction was applied using the SCALE3 ABSPACK algorithm as implemented in the program CrysAlis Pro RED. Twinning was present in the crystal, but the twin law could not be found. Using the program suite WINGX [37], the structure was solved by Patterson interpretation and phase expansion using SHELXL2016 [38], and refined with fullmatrix least squares on $F^{2}$ using SHELXL2016 to give the residuals shown in Table 4. 
All non-hydrogen atoms were refined anisotropically except for a few atoms which had to be refined anisotropically in combination with the instructions DELU and SIMU. A slight disorder was present in one $\mathrm{Cp}$ ligand, which could not be modelled. All hydrogen atoms were geometrically placed and refined using a riding model except for $\mathrm{H}(4)$, which was located on the Fourier maps and refined isotropically; in the latter case, however, a restraint on the $\mathrm{C}(3)-\mathrm{H}(4)$ and $\mathrm{Mo}(1)-\mathrm{H}(4)$ bond lengths was necessary to obtain a satisfactory refinement of its position.

\subsection{DFT calculations.}

All DFT calculations were carried out using the GAUSSIAN03 package [39], in which the hybrid method B3LYP was used with the Becke three-parameter exchange functional [40], and the Lee-Yang-Parr correlation functional [41]. A pruned numerical integration grid $(99,590)$ was used for all the calculations via the keyword Int=Ultrafine. Effective core potentials and their associated double- $\zeta$ LANL2DZ basis set were used for Mo and $\mathrm{W}$ atoms [42]. The light elements ( $\mathrm{P}, \mathrm{O}, \mathrm{C}$ and $\mathrm{H})$ were described with the 6-31G* basis [43]. Geometry optimizations were performed under no symmetry restrictions, using initial coordinates derived from the X-ray data of closely related compounds, and frequency analyses were performed for all the stationary points to ensure that a minimum structure with no imaginary frequencies was achieved. The effect of dichloromethane on the stability of isomers $\mathbf{5 B}$ and $\mathbf{5 T}$ in solution was modelled through the polarized-continuum-model (PCM) of Tomasi and co-workers [44], using the gas-phase optimized structures. The effect of dispersion forces on the relative stability of these isomers was estimated by using the empirical dispersion corrections developed by Grimme [45]. 
Table 4. Crystal data for compound $\mathbf{8}$.

\begin{tabular}{|c|c|}
\hline Mol formula & $\mathrm{C}_{31} \mathrm{H}_{39} \mathrm{MoO}_{2} \mathrm{PW}$ \\
\hline Mol weight & 754.38 \\
\hline Cryst syst & Monoclinic \\
\hline Space group & $P 2{ }_{1} / \mathrm{c}$ \\
\hline Radiation $(\lambda, \AA)$ & 1.54184 \\
\hline$a(\AA)$ & $9.7948(6)$ \\
\hline$b(\AA)$ & $29.0742(15)$ \\
\hline$c(\AA)$ & $10.2085(7)$ \\
\hline$\alpha\left(^{\circ}\right)$ & 90 \\
\hline$\beta\left(^{\circ}\right)$ & $108.666(7)$ \\
\hline$\gamma\left({ }^{\circ}\right)$ & 90 \\
\hline$V\left(\AA^{3}\right)$ & $2754.2(3)$ \\
\hline $\mathrm{Z}$ & 4 \\
\hline Calcd density $\left(\mathrm{g} \mathrm{cm}^{-3}\right)$ & 1.819 \\
\hline Absorp coeff. $\left(\mathrm{mm}^{-1}\right)$ & 12.083 \\
\hline Temperature $(\mathrm{K})$ & $140.0(1)$ \\
\hline$\theta$ range $\left({ }^{\circ}\right)$ & 3.04 to 69.47 \\
\hline index ranges $(h, k, l)$ & $\begin{array}{l}-11,7 ;-31,35 \\
-11,12\end{array}$ \\
\hline No. of reflns collected & 10779 \\
\hline No. of indep reflns $\left(R_{\text {int }}\right)$ & $4636(0.0839)$ \\
\hline Reflns with $[I>2 \sigma(I)]$ & 3953 \\
\hline $\begin{array}{l}\mathrm{R} \text { indexes [data with } \mathrm{I} \\
>2 \sigma(\mathrm{I})]^{a}\end{array}$ & $\begin{array}{l}R_{1}=0.0901 \\
w R_{2}=0.2481^{b}\end{array}$ \\
\hline $\mathrm{R}$ indexes (all data) $)^{b}$ & $\begin{array}{l}R_{1}=0.1064 \\
w R_{2}=0.2743^{b}\end{array}$ \\
\hline GOF & 1.104 \\
\hline No. of restraints/params & $47 / 329$ \\
\hline$\Delta \rho(\max ., \min ),. \mathrm{e}^{-3}$ & $3.447 /-3.521$ \\
\hline CCDC deposition no & 1901013 \\
\hline
\end{tabular}

\section{Acknowledgment}

This work is dedicated to the memory of the late Prof. Pascual Royo, in recognition for his outstanding contribution to Organometallic Chemistry in Spain. This research was funded by the MINECO of Spain and FEDER (Project CTQ2015-63726-P, and a grant to E.H.), and the Consejería de Educación of Asturias (Project GRUPIN14-011). We also thank the X-Ray unit of Universidad de Oviedo, Spain, for acquisition of diffraction data, and the CMC unit of Universidad de Oviedo for access to computing facilities.

\section{Declaration of Interests}

None

\section{Author Information}

* Corresponding authors: E-mail address: garciavdaniel@uniovi.es (D.G.-V.), mara@uniovi.es (M.A.R.). 


\section{Appendix A. Supplementary Data}

An XYZ file containing the Cartesian coordinates for all computed species. CCDC 1901013 contains the supplementary crystallographic data for compound $\mathbf{8}$; these data can be obtained free of charge from The Cambridge Crystallographic Data Centre via www.ccdc.cam.ac.uk/data_request/cif.

\section{References}

[1] (a) F.A. Cotton, G. Wilkinson, Advanced Inorganic Chemistry, $5^{\text {th }}$ ed.; Wiley: New York, 1988, Chapter 22. (b) J.E. Ellis, Adv. Organomet. Chem. 31 (1990) 151. (c) J.E. Ellis, Inorg. Chem. 45 (2006) 3167, and references therein.

[2] (a) C. Chi, S. Pan, L. Meng, M. Luo, L. Zhao, M. Zhou, G. Frenking, Angew. Chem. Int. Ed. 58 (2019) 1732. (b) L. Jin, T. Yang, K. Xin, G. Wang, X. Jin, M. Zhou, G. Frenking, Angew. Chem. Int. Ed. 57 (2018) 6236.

[3] (a) X.Y. Liu, V. Riera, M.A. Ruiz, M. Lanfranchi, A. Tiripicchio, Organometallics 22 (2003) 4500, and references therein.

[4] D. Seyferth, K.S. Brewer, T.G. Wood, M. Cowie, R.W. Hilts, Organometallics 11 (1992) 2570.

[5] (a) M.E. García, S. Melón, A. Ramos, M.A. Ruiz, Dalton Trans. (2009) 8171. (b) M.E. García, S. Melón, A. Ramos, V. Riera, M.A. Ruiz, D. Belletti, C. Graiff, A. Tiripicchio, Organometallics 22 (2003) 1983.

[6] M.A. Alvarez, M. Casado-Ruano, M.E. García, D. García-Vivó, M.A. Ruiz, Inorg. Chem. 56 (2017) 11336.

[7] (a) M.A. Alvarez, M.E. García, D. García-Vivó, M.A. Ruiz, M.F. Vega, Organometallics 34 (2015) 870. (b) M.A. Alvarez, M.E. García, D. García-Vivó, M.A. Ruiz, M.F. Vega, Organometallics 29 (2010) 512.

[8] D. García-Vivó, A. Ramos, M.A. Ruiz, Coord. Chem. Rev. 257 (2013) 2143.

[9] M.A. Alvarez, M.E. García, D. García-Vivó, M.A. Ruiz, M.F. Vega, Dalton Trans. 43 (2014) 16044.

[10] In this paper we have adopted a "half-electron" counting convention for complexes displaying bridging hydrides, so hydride isomers $\mathbf{B}$ and $\mathbf{T}$ are both regarded as having a $\mathrm{M} \equiv \mathrm{M}$ bond, thus emphasizing their highly and similarly unsaturated nature. Other authors, however, recommend the adoption of a "halfarrow" convention for all hydride-bridged complexes (see M.L.H. Green, G. Parkin, Struct. Bond. 117 (2017) 79, and references therein). For a recent discussion on both views on hydride-bridged complexes, see reference 11. 
[11] (a) M.L.H. Green, Dalton Trans. 47 (2018) 6628. (b) D. García-Vivó, M.A. Ruiz, Dalton Trans. 47 (2018), 6630.

[12] (a) R.J. Eisenhart, L.J. Clouston, C.C. Lu, Acc. Chem. Res. 48 (2015) 2885. (b) J.P. Krogman, C.M. Thomas, Chem. Commun. 540 (2014) 5115. (c) C.M. Thomas, Comments Inorg. Chem. 32 (2011) 14. (d) J.P. Collman, R. Boulatov, Angew. Chem. Int. Ed. 41 (2002) 3948.

[13] V. Ritleng, M.J. Chetcuti, Chem. Rev. 107 (2007) 797.

[14] (a) S. Clapham, P. Braunstein, N.M. Boag, R. Welter, M.J. Chetcuti, Organometallics 27 (2008) 1758. (b) M. Oishi, M. Oshima, H. Suzuki, Inorg. Chem. 53 (2014) 6634. (c) M. Oishi, M. Kino, M. Saso, M. Oshima, H. Suzuki, Organometallics 31 (2012) 4658. (d) H. Kameo, Y. Nakajima, H. Suzuki, Angew. Chem. Int. Ed. 47 (2008) 10159.

[15] M.E. García, V. Riera, M.A. Ruiz, M.T. Rueda, D. Sáez, Organometallics 21 (2002) 5515.

[16] C.M. Alvarez, M.A. Alvarez, D. García-Vivó, M.E. García, M.A. Ruiz, D. Sáez, L.R. Falvello, T. Soler, P. Herson, Dalton Trans. (2004) 4168.

[17] (a) H.-J. Haupt, A. Merla, U. Flörke, Z. Anorg. Allg. Chem. 620 (1994) 999. (b) H.-J. Haupt, U. Flörke, G. Disse, C. Heinekamp, Chem. Ber. 124 (1991) 2191.

[18] C.M. Alvarez, M.A. Alvarez, M. Alonso, M.E. García, M.T. Rueda, M.A. Ruiz, P. Herson, Inorg. Chem. 45(2006) 9593.

[19] A general trend established for ${ }^{2} J_{\mathrm{XY}}$ in complexes of the type [MCpXYL2] is that $\left|J_{\text {cis }}\right|>\left|J_{\text {trans }}\right|$. See, for instance, reference 20 and B. Wrackmeyer, H.G. Alt, H.E. Maisel, J. Organomet. Chem. 399 (1990) 125.

[20] C.J. Jameson, in Phosphorus-31 NMR Spectroscopy in Stereochemical Analysis, J.G. Verkade, L.D. Quin, Eds., VCH, New York, 1987, Chapter 6.

[21] C.M. Alvarez, M.E. García, M.T. Rueda, M.A. Ruiz, D. Sáez, N.G. Connelly, Organometallics 24 (2005) 650.

[22] P.S. Braterman, Metal Carbonyl Spectra, Academic Press, London, U.K., 1975.

[23] C.M. Alvarez, M.A. Alvarez, M.E. García, A. Ramos, M.A. Ruiz, M. Lanfranchi, A. Tiripicchio, Organometallics 24 (2005) 7.

[24] (a) C.J. Cramer, Essentials of Computational Chemistry, 2nd Ed.; Wiley: Chichester, UK, 2004. (b) W. Koch, M.C. Holthausen, A Chemist's Guide to Density Functional Theory, 2nd Ed.; Wiley-VCH: Weinheim, 2002.

[25] (a) R.M. Bullock, Comments Inorg. Chem. 12 (1991) 1. (b) J.A. Martinho Simoes, J.L. Beauchamp, Chem. Rev. 90 (1990) 629. (c) R.G. Pearson, Chem. Rev. 85 (1985) 41.

[26] R.H. Crabtree, M. Lavin, Inorg. Chem. 25 (1986) 805. 
[27] V.A. Levina, O.A. Filippov, E.I. Gutsul, N.V. Belkova, L.M. Epstein, A. Lledós, E.S. Shubina, J. Am. Chem. Soc. 132 (2010) 11234, and references therein.

[28] M.A. Alvarez, M.E. García, D. García-Vivó, M.E. Martínez, M.A. Ruiz, Organometallics 30 (2011) 2189.

[29] M.E. García, A. Ramos, M.A. Ruiz, M. Lanfranchi, L. Marchió, Organometallics 26 (2007) 6197.

[30] The $\eta^{2}$-coordination of the alkyl ligand likely will be stronger also at the $\mathrm{W}$ (vs. Mo) site; however, since the strength of the $\eta^{2}$-coordination (below ca. 100 $\mathrm{kJ} / \mathrm{mol}$ ) is much lower than the strength of the $\kappa^{1}$-coordination (around 200 $\mathrm{kJ} / \mathrm{mol}$ ), the overall thermodynamic balance will be in favour of $\kappa^{1}$-coordination to the $\mathrm{W}$ atom.

[31] M.A. Alvarez, M.E. García, D. García-Vivó, M.E. Martínez, A. Ramos, M.A. Ruiz, Organometallics 27 (2008) 1973.

[32] T. Adatia, M. McPartlin, M.J. Mays, M.J. Morris, P.R. Raithby, J. Chem. Soc., Dalton Trans (1989) 1555.

[33] M.E. García, D. García-Vivó, M.A. Ruiz, S. Alvarez, G. Aullón, Organometallics 26 (2007) 4930.

[34] W.L.F. Armarego, C.C.C. Chai, Purification of Laboratory Chemicals, 7th ed., Butterworth-Heinemann, Oxford, U. K., 2012.

[35] R. Birdwhistell, P. Hackett, A.R. Manning, J. Organomet. Chem. 157 (1978) 239.

[36] CrysAlis Pro, Oxford Diffraction Limited, Ltd., Oxford, U. K., 2006.

[37] L.J. Farrugia, J. Appl. Crystallogr. 32 (1999) 837.

[38] (a) G.M. Sheldrick, Acta Crystallogr., Sect. A, 64 (2008) 112. (b) G.M. Sheldrick, Acta Crystallogr., Sect. C, 71 (2015) 5.

[39] Frisch, M. J.; Trucks, G. W.; Schlegel, H. B.; Scuseria, G. E.; Robb, M. A.; Cheeseman, J. R.; Montgomery, Jr., J. A.; Vreven, T.; Kudin, K. N.; Burant, J. C.; Millam, J. M.; Iyengar, S. S.; Tomasi, J.; Barone, V.; Mennucci, B.; Cossi, M.; Scalmani, G.; Rega, N.; Petersson, G. A.; Nakatsuji, H.; Hada, M.; Ehara, M.; Toyota, K.; Fukuda, R.; Hasegawa, J.; Ishida, M.; Nakajima, T.; Honda, Y.; Kitao, O.; Nakai, H.; Klene, M.; Li, X.; Knox, J. E.; Hratchian, H. P.; Cross, J. B.; Bakken, V.; Adamo, C.; Jaramillo, J.; Gomperts, R.; Stratmann, R. E.; Yazyev, O.; Austin, A. J.; Cammi, R.; Pomelli, C.; Ochterski, J. W.; Ayala, P. Y.; Morokuma, K.; Voth, G. A.; Salvador, P.; Dannenberg, J. J.; Zakrzewski, V. G.; Dapprich, S.; Daniels, A. D.; Strain, M. C.; Farkas, O.; Malick, D. K.; Rabuck, A. D.; Raghavachari, K.; Foresman, J. B.; Ortiz, J. V.; Cui, Q.; Baboul, A. G.; Clifford, S.; Cioslowski, J.; Stefanov, B. B.; Liu, G.; Liashenko, A.; Piskorz, P.; Komaromi, I.; Martin, R. L.; Fox, D. J.; Keith, T.; Al-Laham, M. A.; Peng, C. Y.; Nanayakkara, A.; Challacombe, M.; Gill, P. M. W.; Johnson, B.; Chen, W.; 
Wong, M. W.; Gonzalez, C.; and Pople, J. A.; Gaussian 03, Revision B.02; Gaussian, Inc.: Wallingford, CT, 2004.

[40] A.D. Becke, J. Chem. Phys. 98 (1993) 5648.

[41] C. Lee, W. Yang, R.G. Parr, Phys. Rev. B 37 (1988) 785.

[42] P.J. Hay, W.R. Wadt, J. Chem. Phys. 82 (1985) 299.

[43] (a) P.C. Hariharan, J.A. Pople, Theor. Chim. Acta 28 (1973) 213. (b) G.A. Petersson, M.A. Al-Laham, J. Chem. Phys. 94 (1991) 6081. (c) G.A. Petersson, A. Bennett, T.G. Tensfeldt, M.A. Al-Laham, W.A. Shirley, J. Mantzaris, J. Chem. Phys. 89 (1988) 2193.

[44] M. Cossi, V. Barone, R. Cammi, J. Tomasi, Chem. Phys. Lett. 255 (1996) 327, and references therein.

[45] S. Grimme, J. Comput. Chem. 27 (2006) 1787. 


\section{For Graphical Abstract Use Only}

\section{Synopsis}

Hydride and alkyl derivatives of the title anion display structural and chemical properties different from their homometallic analogues: a higher preference of the hydride ligand for terminal coordination, a marked preference of hydride and alkyl ligands for the tungsten site, and an easier methyl dehydrogenation yielding the corresponding methylidyne derivative.

\section{Pictogram for Graphical Abstract}

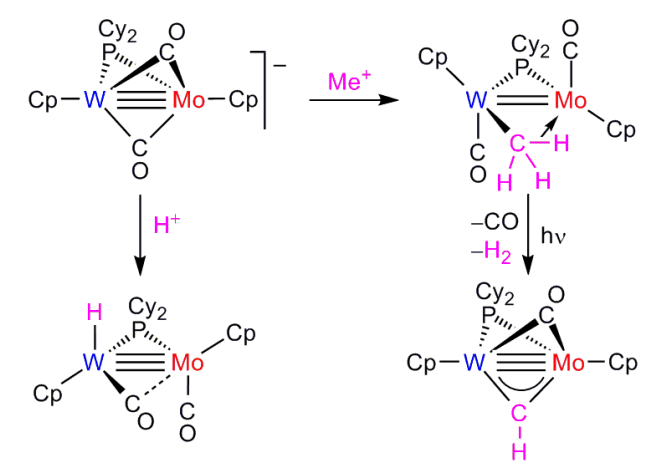

